\title{
Effect of neutron irradiation on select MAX phases
}

Darin J. Tallman ${ }^{1, *}$, Elizabeth N. Hoffman ${ }^{2}$, El'ad N. Caspi ${ }^{1, a}$, Brenda Garcia-Diaz ${ }^{2}$, Gordon Kohse ${ }^{3}$, Robert L. Sindelar ${ }^{2}$, Michel W. Barsoum ${ }^{1}$

${ }^{1}$ Department of Materials Science and Engineering, Drexel University, Philadelphia, PA 19104, USA

\author{
${ }^{2}$ Savannah River National Lab, Savannah River Site, Aiken, SC 29808, USA \\ ${ }^{3}$ MIT Nuclear Reactor Laboratory, Massachusetts Institute of Technology, Cambridge, MA
} 02139, USA

${ }^{a}$ On sabbatical leave from the Nuclear Research Centre, Negev, Israel

*Corresponding author. Tel.: +16092020771.

E-mail addresses: darintallman@gmail.com; djt332@drexel.edu (D.J. Tallman).

\begin{abstract}
Herein we report on the effect of neutron irradiation - of up to 0.1 displacements per atom at $360(20)^{\circ} \mathrm{C}$ or $695(25)^{\circ} \mathrm{C}-$ on polycrystalline samples of $\mathrm{Ti}_{3} \mathrm{AlC}_{2}, \mathrm{Ti}_{2} \mathrm{AlC}, \mathrm{Ti}_{3} \mathrm{SiC}_{2}$ and $\mathrm{Ti}_{2} \mathrm{AlN}$. X-ray diffraction refinement of the irradiated samples showed irradiation-enhanced dissociation into $\mathrm{TiC}$ of the $\mathrm{Ti}_{3} \mathrm{AlC}_{2}$ and $\mathrm{Ti}_{3} \mathrm{SiC}_{2}$ phases, most prominently in the former. $\mathrm{Ti}_{2} \mathrm{AlN}$ also showed an increase in TiN content, as well as $\mathrm{Ti}_{4} \mathrm{AlN}_{3}$ after irradiation. In contrast, $\mathrm{Ti}_{2} \mathrm{AlC}$ was quite stable under these irradiation conditions. Dislocation loops a re seen to form in $\mathrm{Ti}_{2} \mathrm{AlC}$ and $\mathrm{Ti}_{3} \mathrm{AlC}_{2}$ after ir radiation at $360(20)^{\circ} \mathrm{C}$. The room temperature electrical resistivity of all samples increased by an order of magnitude after irradiation at $360(20)^{\circ} \mathrm{C}$, but onl y by $25 \%$ after $695(25)^{\circ} \mathrm{C}$, providing e vidence for the MA X pha ses' dy namic recovery at temperatures as low at $695(25)^{\circ} \mathrm{C}$. Based on these preliminary results, it appears that $\mathrm{Ti}_{2} \mathrm{AlC}$ and $\mathrm{Ti}_{3} \mathrm{SiC}_{2}$ are the more promising materials for high-temperature nuclear applications.
\end{abstract}

Keywords: $\mathrm{Ti}_{2} \mathrm{AlC} ; \mathrm{Ti}_{3} \mathrm{SiC}_{2} ; \mathrm{Ti}_{3} \mathrm{AlC}_{2} ;$ Neutron irradiation; Rietveld refinement 


\section{Introduction}

Gen IV nuclear reactor designs require $m$ aterials that can w ithstand long-term operation in e xtreme environments of el evated temperatures, corrosive m edia and f ast ne utron f luences $\mathrm{w}$ ith up to 100 displacements per atom (dpa) [1]. A full understanding of the irradiation response in selected materials is paramount t o 1 ong-term, reliable ser vice. The $\mathrm{M}_{n+1} \mathrm{AX}_{n}$ (MAX) pha ses ar e a cl ass of 1 ayered, machinable, ternary carbides and/or nitrides, where $\mathrm{M}$ is an early transition metal, $\mathrm{A}$ is a group 13 to 16 element and $\mathrm{X}$ is $\mathrm{C}$ and/or $\mathrm{N}$. These compounds pos sess a unique set of properties, both metallic and ceramic in nature. For example, some of them exhibit relatively high fracture toughness values ( 8-12 MPa $\sqrt{ } \mathrm{m}$ ) and are elastically stiff like their binary carbide and nitride counterparts, and yet are readily machinable, 1 ightweight and relatively soft [2-6]. The M AX phases a lso unde rgo plastic-to-brittle transitions at high temperatures, and the materials can w ithstand hi gh compressive st resses at room temperature (RT) [2,5]. Al-containing MAX phases also show excellent oxidation resistance in air and in the presence of water vapor [7-10].

Many recent studies have explored the damage tolerance and amorphization resistance of several MAX phases irradiated with heavy ions [11-21]. In 2009, Nappé et al. explored the effect of $90 \mathrm{MeV}$ Xe ions on $\mathrm{Ti}_{3} \mathrm{SiC}_{2}$, showing surface layer amorphization of the $\mathrm{Ti}_{3} \mathrm{SiC}_{2}$ and impurity phases, as well as selective grain bound ary s puttering due to nuclear in teractions [11]. Liu et al. characterized Al-doped $\mathrm{Ti}_{3} \mathrm{SiC}_{2}$, irradiated to a maximum dose of 3.25 dpa with high-energy $\mathrm{Kr}$ and $\mathrm{Xe}$ ions, via $\mathrm{X}$-ray diffraction (XRD) and na noindentation s howing a $\mathrm{n}$ e xpansion of the $\mathrm{c}$-lattice pa rameter, c-LP, a nd i rradiation-induced hardness that could be annealed out at $800^{\circ} \mathrm{C}[16,17]$. They also reported the possible existence of a $\beta$ $\mathrm{Ti}_{3} \mathrm{SiC}_{2}$ phase to explain the presence of new peaks found in the post-irradiated XRD patterns [17]. Soon after, Le F lem et al. reported on selected area diffraction (SAD) patterns in a transmission electron microscope (TEM) of $\mathrm{Ti}_{3}(\mathrm{Si}, \mathrm{Al}) \mathrm{C}_{2}$ irradiated with $92 \mathrm{M} \mathrm{eV} \mathrm{X} \mathrm{e} \mathrm{i} \mathrm{ons} \mathrm{up} \mathrm{to} 6.67 \mathrm{dpa}$, w hich further 
confirmed this MAX phases' resistance to amorphization [18]. With increasing dose, diffraction peaks were found to disappear due to lattice disturbances. In 2010, Bugnet et al. explored the effect of $100 \mathrm{keV}$ $\mathrm{Ar}^{2+}$ ion irradiation on multilayered $(\mathrm{Ti}, \mathrm{Al}) \mathrm{N} / \mathrm{Ti}_{2} \mathrm{AlN}_{x}$ nitrogen-deficient thin films, re porting that the multilayered structure was preserved up to a dose of 12 dpa, likely due to nitrogen vacancies acting as sinks for interstitial point defects [21].

Along the same lines, Whittle et al. reported that $\mathrm{Ti}_{3} \mathrm{AlC}_{2}$ and $\mathrm{Ti}_{3} \mathrm{SiC}_{2}$ possess very high resistance to amorphization, e ven up t o $25 \mathrm{dpa}$, irradiated with $1 \mathrm{MeV} \mathrm{Kr}^{2+}$ and $1 \mathrm{MeV} \mathrm{Xe}^{2+}$ [15]. Nappé et al. reported that nuclear collisions with $4 \mathrm{MeV}$ Au ions, up to a dose of $4.3 \mathrm{dpa}$, resulted in a $2.2 \%$ swelling in $\mathrm{Ti}_{3} \mathrm{SiC}_{2}$ [12]. Also in 2011, Nappé et al. investigated the structural changes of $\mathrm{Ti}_{3} \mathrm{SiC}_{2}$ under a variety of ions and energies, concluding that $\mathrm{Ti}_{3} \mathrm{SiC}_{2}$ is not sensitive to electrical interactions, and confirmed that nuclear collisions lead to an increase in c-LP and a decrease in the a lattice parameter, a-LP, and a concomitant increase in lattice microstrains [14]. In 2012, Zhang et al. reported that a TiC and/or 3C$\mathrm{SiC}$ (cubic $\beta$ ) nanocrystalline phase formed under $2 \mathrm{MeV} \mathrm{I}^{2+}$ irradiation of $\mathrm{Ti}_{3} \mathrm{SiC}_{2}$, though the material did not fully de compose, e ven up to 10.3 dp a [20]. In 2 013, Le Flem and Monnet reported on a saturation in irradiation damage at $3.2 \mathrm{dpa}$ via hardness measurements and cell volume expansion due to defect formation under $92 \mathrm{MeV}$ Xe ions in $\mathrm{Ti}_{3} \mathrm{SiC}_{2}[19]$.

It is important to note that, in contrast to neutrons, which pass through the bulk, the penetration depth of heavy ion and $\mathrm{He}$ irradiation is limited to the subsurface, and $\mathrm{He}$ atoms tend to accumulate and form bubbles inside the material after momentum transfer. This has been illustrated by Xiao et al. via ab initio methods, showing the He most energetically favors Al-site interstitials in $\mathrm{Ti}_{3} \mathrm{AlC}_{2}$ [22]. More recently, Wang et al. irradiated $\mathrm{Ti}_{3} \mathrm{AlC}_{2}$ samples with $50 \mathrm{keV}$ He ions with fluences ranging from $8 \times 10^{16} \mathrm{~cm}^{-2}$ to $1 \times 10^{18} \mathrm{~cm}^{-2}$, resulting in the formation of spherical He bubbles, string-like bubbles and faulting zones [23]. Grazing incidence X RD an alysis and selected area electron diffraction (SAED) confirmed 
significant structural disorder without amorphization, even up to $52 \mathrm{~d}$ pa. Patel et al. irradiated $\mathrm{Ti}_{3} \mathrm{AlC}_{2}$ samples with $200 \mathrm{keV} \mathrm{He}$ ions to a maximum dose of $5.5 \mathrm{dpa}$ at $500^{\circ} \mathrm{C}$, and showed, by careful analysis of XRD patterns, that the $\mathrm{Ti}_{3} \mathrm{AlC}_{2}$ structure was maintained, but with an increased c-LP and a decreased a-LP, together with a highly disordered Al layer [24]. If He bubbles exist, they were $<1 \mathrm{~nm}$ in diameter and did not agglomerate, as observed by Wang et al. at RT [23]. Very recently, Yang et al. reported on the structural transitions of $\mathrm{Ti}_{3} \mathrm{AlC}_{2}$ irradiated with $50 \mathrm{keV} \mathrm{He}$ ions over a wide fluence range. While no amorphization was de tected up t o $31 \mathrm{dpa}$, antisite de fects readily de stroyed the nanolamellar $\mathrm{Ti}_{3} \mathrm{AlC}_{2}$ structure, and a transition to $\beta-\mathrm{Ti}_{3} \mathrm{AlC}_{2}$ was observed above $2.61 \mathrm{dpa}$ [25].

In addition to heavy ion and He irradiation studies, Hoffman et al. have shown that neutron activation of $\mathrm{Ti}_{3} \mathrm{SiC}_{2}, \mathrm{Ti}_{3} \mathrm{AlC}_{2}$ and $\mathrm{Ti}_{2} \mathrm{AlC}$ compare well to $\mathrm{SiC}$ and are three orders of magnitude lower than alloy 617, two candidate materials for use in next generation reactors [26].

Based on these pr eliminary $r$ esults it has be en pr oposed that the MAX pha ses could be used in demanding nuclear environments either as fuel matrices or as coating materials, with the potential for significant i mprovements i $\mathrm{n}$ pe rformance due t ot heir high-temperature capa bilities, high damage tolerance, chemical resistance and versatile manufacturing techniques. The pur pose of this w ork is to understand the effects of neutron irradiation on the microstructural stability and electrical resistivity of polycrystalline samples of $\mathrm{Ti}_{3} \mathrm{AlC}_{2}, \mathrm{Ti}_{3} \mathrm{SiC}_{2}, \mathrm{Ti}_{2} \mathrm{AlC}$ and $\mathrm{Ti}_{2} \mathrm{AlN}$. As far as we are aware, and with the exception of a report that has just been published, on the neutron irradiation of $\mathrm{Ti}_{3} \mathrm{SiC}_{2}$ formed at joints between $\mathrm{SiC}$ parts, this is the first report on the neutron irradiation of bulk MAX phases in the open literature.

\section{Experimental details}

Details of the synthesis and processing conditions of the MAX phases are discussed elsewhere $[5,27]$. In short, samples of $\mathrm{T} \mathrm{i}_{2} \mathrm{AlC} \mathrm{w}$ ere prepared by pour ing pr e-reacted $\mathrm{Ti}_{2} \mathrm{AlC}$ pow ders (Kanthal, 
Hallstahammar, Sweden) into graphite dies, which were loaded into a vacuum hot press and hot pressed (HPed) for $4 \mathrm{~h}$ unde $\mathrm{ra} 1$ oad c orresponding to a s tress of $\sim 40 \mathrm{M} \mathrm{Pa}$ and a va cuum of $10^{-1} \mathrm{~Pa}$ at a temperature of $1300^{\circ} \mathrm{C}$. The $\mathrm{Ti}_{3} \mathrm{AlC}_{2}$ samples were fabricated by ball milling stoichiometric mixtures of pre-reacted $\mathrm{Ti}_{2} \mathrm{AlC}$ and $\mathrm{TiC}$ powders (Alfa A esar, Ward Hill, MA, USA) for $24 \mathrm{~h}$. The latter were, in turn, HPed at $1400^{\circ} \mathrm{C}$ for $4 \mathrm{~h}$. The $\mathrm{Ti}_{2} \mathrm{AlN}$ samples were fabricated by milling stoichiometric mixtures of Ti and AlN powders (Alfa Aesar, Ward Hill, Massachusetts, USA) as a bove, and then HPing them at $1300^{\circ} \mathrm{C}$ for $4 \mathrm{~h}$. Fine-grained samples of $\mathrm{Ti}_{3} \mathrm{SiC}_{2}$, henceforth referred to as $\mathrm{Ti}_{3} \mathrm{SiC}_{2}-\mathrm{FG}$, were prepared by ball milling stoichiometric mixtures of $\mathrm{Ti}, \mathrm{Si}$ and $\mathrm{C}$ powders (Alfa Aesar, Ward Hill, MA, USA) for $24 \mathrm{~h}$, which were then HPed at $1450^{\circ} \mathrm{C}$ for 6 h. C oarse-grained $\mathrm{Ti}_{3} \mathrm{SiC}_{2}$, henceforth referred to as $\mathrm{Ti}_{3} \mathrm{SiC}_{2}-\mathrm{CG}$, was prepared from elemental mixtures as above, and $\mathrm{HPed}$ at $1500^{\circ} \mathrm{C}$ for $4 \mathrm{~h}$, followed by an anneal at $1600^{\circ} \mathrm{C}$ for $8 \mathrm{~h}$ in an argon atmosphere in order to grow the grains.

Samples of each phase were sectioned, mounted in epoxy and polished with a final surface preparation of $3 \mu \mathrm{m}$ di amond s uspension for observation unde $\mathrm{r}$ a $\mathrm{n}$ o ptical $\mathrm{m}$ icroscope ( $\mathrm{OM})$. T he M AX pha se microstructure was exposed with an etchant composed of 1:1:1 parts by volume solution of hydrofluoric acid (50 vol.\%), nitric acid (70 vol.\%) and water, which was applied to the surface for $<30 \mathrm{~s}$ and rinsed. This etchant resulted in vibrantly colored MAX phase grains, notably in $\mathrm{Ti}_{3} \mathrm{AlC}_{2}$ (Fig. 1b) and $\mathrm{Ti}_{3} \mathrm{SiC}_{2}$ (Fig. 1d and e) with well-exposed grain boundaries. In these micrographs, TiC appears as bright white grains, highlighted in Fig. 1 by white arrows. The length, $d_{1}$, and thickness, $d_{\mathrm{t}}$, of $>100$ grains per sample were measured from OM micrographs. The equivalent grain size was calculated as the geometric mean value of the grain dimensions, i.e. $\sqrt[3]{d_{l}^{2} \cdot d_{t}}$. Test specimens were electro-discharged machined into 1.5 $\times 1.5 \times 25.4 \mathrm{~mm}^{3}$ resistivity bars, $16 \times 4 \times 0.7 \mathrm{~mm}^{3}$ tensile dogbone s and $0.5 \mathrm{~mm}$ thick and $3 \mathrm{~mm}$ diameter disks for TEM observation. In all cases, the initial dimensions were recorded. 
Specimens were i rradiated in a $6 \mathrm{MW}$ r esearch reactor at the Massac husetts Institute of Technology Nuclear Reactor Laboratory in a neutron spectrum similar to that of a light water power reactor. Samples were irradiated to a total fluence of $3.4 \times 10^{20} \mathrm{n} \mathrm{cm}^{-2}$ at $360(20)^{\circ} \mathrm{C}$, denoted henceforth as LT, and to 4.8 $\times 10^{20} \mathrm{n} \mathrm{cm}^{-2}$ at $695(25)^{\circ} \mathrm{C}$, de noted as HT. The samples were irradiated in an inert gas atmosphere consisting of a mixture of high-purity ( $>99.99 \%)$ helium and neon and were in contact only with clean titanium (CP Grade 2). The effluent gas was periodically monitored for impurities using a residual gas analyzer, $w$ ith typical $v$ alues for ox ygen and $w$ ater of a few $\mathrm{pp} \mathrm{m}$. T he i rradiation $t$ emperature $\mathrm{w}$ as monitored using a thermocouple in each capsule. Calculations using Fluent ${ }^{\mathrm{TM}}$ show that the temperature variation across the sample capsule is less than $\sim \pm 10 \mathrm{~K}$. Note that the fluences are based on the actual integrated MWh for each set of specimens and Monte $\mathrm{C}$ arlo N-Particle T ransport C ode (MCNP) calculated flux levels at the irradiation positions. Using the SiC damage cross-sections reported in Ref. [28] as a function of neutron energy and spectral da ta from MCNP for a similar in-core experimental position, the dpa in each energy bin per neutron of total fluence was calculated for SiC [29]. Integrating over all ne utron energies leads to a dpa conversion of $4 \times 10^{21} \mathrm{n} \mathrm{cm}^{-2}$ total fluence $=1 \mathrm{dpa}$. Using this damage rate for MAX phases, in the absence of other damage cross-section data, this work explores the irradiation response in the 0.1 dpa regime, henceforth denoted as low dose. Characterization of samples irradiated up to $20 \times 10^{20} \mathrm{n} \mathrm{cm}^{-2}$ and $30 \times 10^{20} \mathrm{n} \mathrm{cm}^{-2}$ is underway, and is not covered herein.

XRD patterns from the surfaces of samples of $\mathrm{Ti}_{2} \mathrm{AlC}, \mathrm{Ti}_{3} \mathrm{AlC}_{2}, \mathrm{Ti}_{2} \mathrm{AlN}, \mathrm{Ti}_{3} \mathrm{SiC}_{2}-\mathrm{FG}$ and $\mathrm{Ti}_{3} \mathrm{SiC}_{2}-\mathrm{CG}$ were obtained using one of two diffractometers (Bruker D8, Madison, WI, USA) in the Bragg-Brentano configuration, for pristine a nd irradiated c onditions, respectively. The di ffractograms w ere c ollected using step scans of $0.02^{\circ}$ in the $5-70^{\circ} 2 \theta$ range, with a step time of $2 \mathrm{~s}$. Scans were made with $\mathrm{Cu} \mathrm{K} \alpha$ radiation ( $45 \mathrm{kV}$ and $40 \mathrm{~mA}$ ). The accuracy of the diffractometer in determining lattice parameters, and its instrumental peak-shape function parameters, were calibrated using a $\mathrm{LaB}_{6}$ standard (NIST 660A). 
All di ffractograms w ere a nalyzed by the $\mathrm{R}$ ietveld $\mathrm{r}$ efinement method, us ing t he F ULLPROF c ode [30,31]. A s ystematic shift of $0.02 \% \mathrm{w}$ as found, a nd c orrected for, in the lattice parameters' (LPs'), evaluation as compared to the $\mathrm{LaB}_{6}$ standard's reported value. For each data set, a model containing TiC and each specific MAX phase, e.g., $\mathrm{Ti}_{3} \mathrm{SiC}_{2}, \mathrm{Ti}_{3} \mathrm{AlC}_{2}$ or $\mathrm{Ti}_{2} \mathrm{AlC}$, was refined. For $\mathrm{Ti}_{2} \mathrm{AlN}$, the model was refined with the TiN and $\mathrm{Ti}_{4} \mathrm{AlN}_{3}$ phases. The Thompson-Cox-Hastings pseudo-Voigt model was used to refine the peak shape of each phase's reflections. Lattice strains and particle sizes were also estimated assuming $\mathrm{i}$ sotropic $\mathrm{L}$ orenzian a nd $\mathrm{G}$ aussian contributions t ot he $\mathrm{p}$ eak $\mathrm{s}$ hape function [32]. The microstrain was calculated from the full width half maximum (FWHM) parameter $\mathrm{U}$ from each sample, according to the following equation:

$$
\% \mu \epsilon=\frac{\pi}{1.8}\left(\sqrt{U_{\text {sample }}-U_{\text {std }}}\right)
$$

where $U_{\text {std }}$ was refined from the $\mathrm{LaB}_{6}$ standard. If $U_{\text {sample }}$ refined lower than the $U_{\text {std }}$, the microstrain was unresolvable for that specimen. The $U_{\text {std }}$ values were $0.006(2)$ and $0.014(2)$ for the standards scanned on the diffractometers for pristine and irradiated samples, respectively.

Microstructural analysis of irradiation defects was carried out on the $\mathrm{Ti}_{2} \mathrm{AlC}$ and $\mathrm{Ti}_{3} \mathrm{AlC}_{2}$ samples using a TEM (JEOL 2010, Japan). TEM disks were mechanically polished with 1200 grit $\mathrm{SiC}$ paper down to a thickness of $<50 \mu \mathrm{m}$ a nd e lectropolished (Model $110 \mathrm{~T}$ win J et, F ischione Instruments, E xton, P A, USA) in a $95 \mathrm{vol} . \%$ methanol, $5 \mathrm{v}$ ol. $\%$ perchloric acid solution to produce electron transparent edges around perforations that formed in the samples. Bright field (BF) and weak be am g3g c ondition TEM micrographs, as well as SAED patterns, were collected to characterize the irradiation defects. Lacking detailed information on the lamella thicknesses, the defect density per $\mathrm{m}^{2}$ was measured to compare the defect density qualitatively between sample conditions in this study. Rigorous TEM characterization of the defects found in these materials is the focus of a future study. 
Pre- and post-irradiation RT resistivity $(\rho)$ measurements were obtained for all samples using a fourpoint probe technique using a current of $100 \mathrm{~mA}$. Three resistivity bars of each material were irradiated at each condition, and the recorded values w ere ave raged from the multiple bars tested. Since some resistivity b ars were broken upon retrieval, in some cases the ave rage of only two resistivity bars is reported. Voltages were recorded once per second for $3 \mathrm{~min}$ to allow the scans to reach steady state, and averaged over time. For most samples a time-independent voltage signal was recorded. Occasionally, a $\mathrm{Ti}_{3} \mathrm{AlC}_{2}$ and $\mathrm{Ti}_{2} \mathrm{AlC}$ sample would exhibit a noisy signal. Lightly polishing the surfaces with 600 grit grinding paper solved the problem and resulted in steady voltage measurements.

\section{Results}

OM micrographs of the resulting samples showed them to be fully de nse and predominately single phase, with randomly aligned plate-like grains (Fig. 1a-e). The average grain sizes of the $\mathrm{Ti}_{3} \mathrm{SiC}_{2}-\mathrm{FG}$ and $\mathrm{Ti}_{3} \mathrm{SiC}_{2}-\mathrm{CG}$, w ere 8(3) and $50(20) \mu \mathrm{m}$, r espectively, with uncertainty listed in parentheses. The average grain sizes of $\mathrm{Ti}_{2} \mathrm{AlC}, \mathrm{Ti}_{2} \mathrm{AlN}$ and $\mathrm{Ti}_{3} \mathrm{AlC}_{2}$ were 10(4), 15(2) and 16(6) $\mu \mathrm{m}$, respectively.

The XRD patterns collected from the $\mathrm{Ti}_{3} \mathrm{SiC}_{2}-\mathrm{FG}, \mathrm{Ti}_{3} \mathrm{SiC}_{2}-\mathrm{CG}, \mathrm{Ti}_{3} \mathrm{AlC}_{2}, \mathrm{Ti}_{2} \mathrm{AlC}$ and $\mathrm{Ti}_{2} \mathrm{AlN}$ samples before and after the L T and $\mathrm{H}$ T i rradiations are shown in Figs. 2-6, respectively. The results of the Rietveld an alyses of these pa tterns a re s ummarized in $\mathrm{T}$ able 1 . A ccording to these re sults, the $\mathrm{T} \mathrm{iC}$ contents of the pristine $\mathrm{Ti}_{2} \mathrm{AlC}, \mathrm{Ti}_{3} \mathrm{AlC}_{2}, \mathrm{Ti}_{3} \mathrm{SiC}_{2}-\mathrm{FG}$ and $\mathrm{Ti}_{3} \mathrm{SiC}_{2}-\mathrm{CG}$ samples were found to be 6.7(8) wt.\%, 1.9(6) wt.\%, 20.0(5) wt.\% and 18.2(5) wt.\%, respectively. While no $\mathrm{Ti}_{4} \mathrm{AlN}_{3}$ phase was observed in pristine $\mathrm{Ti}_{2} \mathrm{AlN}$, the TiN content was found to be 3.2(2) wt. $\%$.

In all cases, the neutron irradiations resulted in structural as well as compositional changes compared to their pristine conditions ( Table 1). The be st fit of the X RD pa tterns was a chieved by i ncluding T iC during refinement of the $\mathrm{c}$ arbide phases. Irradiation of the $\mathrm{Ti}_{3} \mathrm{AlC}_{2}$ samples resulted in the significant increase in the TiC content from 1.9(6) wt.\% before irradiation, to 52.6(9) and 44.4(8) wt.\% after the LT 
and H T i rradiations, r espectively. Cross-sections of these samples w ere al so scan ned by XRD ( not shown), confirming that the dissociation into $\mathrm{TiC}$ was not a surface phenomenon. Irradiation of $\mathrm{Ti}_{3} \mathrm{SiC}_{2}-$ FG also yielded an increase in TiC content, going from 20.0(5) wt.\% initially to 22.7(5) and 25(1) wt.\% after the $\mathrm{LT}$ and $\mathrm{HT}$ irradiations, respectively. The $\mathrm{TiC}$ content in the $\mathrm{Ti}_{3} \mathrm{SiC}_{2}-\mathrm{CG}$ changed from 18.2(5) wt.\% as received to 23.3(6) and 17.0(4) wt.\% after LT and HT irradiations, respectively (Table 1).

The Rietveld refinement of the XRD pattern of the $\mathrm{Ti}_{3} \mathrm{SiC}_{2}-\mathrm{FG}$ sample irradiated at $360(20)^{\circ} \mathrm{C}$, denoted henceforth as $\mathrm{Ti}_{3} \mathrm{SiC}_{2}$-FG-LT, showed an increase in the c-LP from 17.681(1) to 17.812(9) $\AA$ and a decrease in the a-LP f rom 3.0686 (8) to 3.064 8(1) $\AA$ (Figs. 2 a nd 7). A microstrain of $0.27 \% \mathrm{w}$ as calculated for the distorted lattice; an increase from $0.08 \%$ in the pristine sample (Table 1). The lattice of the $\mathrm{Ti}_{3} \mathrm{SiC}_{2}-\mathrm{FG}$ sample irradiated at $695(25)^{\circ} \mathrm{C}$, henceforth referred to as $\mathrm{Ti}_{3} \mathrm{SiC}_{2}-\mathrm{FG}-\mathrm{HT}$, was only slightly perturbed, with a c-LP of 17.668(1) and an a-LP of 3.0674(1) (Figs. 2c and 7 and Table 1).The microstrain level was below that of the standard used to calibrate the diffractometer.

The $\mathrm{Ti}_{3} \mathrm{SiC}_{2}$-CG samples behaved similarly to their fine-grained counterparts (Fig. 3). Refinement of the XRD pa tterns of the $\mathrm{Ti}_{3} \mathrm{SiC}_{2}$-CG-LT sam ple r evealed an i ncrease i $\mathrm{t} t$ he $\mathrm{c}$-LP $\mathrm{f}$ rom 17.680 (8) to $17.840(8) \AA$ a nd a de crease in the a -LP from 3.0688(7) to 3.0647( 8) $\AA$. T here w as a s imultaneous increase in microstrain to $0.33 \%$ (Table 1). After irradiation at $695(25)^{\circ} \mathrm{C}$, the $\mathrm{Ti}_{3} \mathrm{SiC}_{2}-\mathrm{CG}$ lattice was slightly distorted, with a c-LP of 17.669(6) $\AA$, an a-LP of 3.0674(8) $\AA$ (Fig. 7); the microstrain was only $0.06 \%$.

The Rietveld refinement of $\mathrm{Ti}_{3} \mathrm{AlC}_{2}-\mathrm{LT}$ XRD patterns (Fig. 4a and b) also showed an increase in the cLP from 18.562(2) to 18.896(1) $\AA$ and a decrease in a-LP from 3.0736(2) to 3.0542(2) $\AA$ (Table 1). Concomitantly there $\mathrm{w}$ as a $\mathrm{n}$ increase in microstrain from $0.1 \%$ to $0.39 \%$ (F ig. $4 \mathrm{~b}$ and Table 1$)$. At 18.543(2) $\AA$ a nd 3.0699(2) $\AA$, the c - and a-LPs, r espectively, of the $\mathrm{Ti}_{3} \mathrm{AlC}_{2}-\mathrm{HT}$ sam ples w ere 1 ess distorted than those at LT (Figs. $4 \mathrm{c}$ and 7). After irradiation at $695(25)^{\circ} \mathrm{C}$, the microstrain was $0.34 \%$. 
As noted above, pristine $\mathrm{Ti}_{2} \mathrm{AlC}$ samples were fabricated using commercially available MAX powders (Kanthal, Sweden), resulting in an initial TiC volume fraction of 6.7(8) wt.\%. At 8.3(3) wt.\%, the TiC composition di $\mathrm{d}$ not $\mathrm{c}$ hange a fter the $\mathrm{L} \mathrm{T}$ i rradiation a nd $\mathrm{w}$ as $\mathrm{w}$ ithin the va riability in $\mathrm{T}$ iC $\mathrm{c}$ ontent obtained $\mathrm{f}$ or $\mathrm{t}$ hese $\mathrm{s}$ amples. The 1 attice pa rameters of $\mathrm{t}$ he $\mathrm{T} \mathrm{i}_{2} \mathrm{AlC}-\mathrm{HT} \mathrm{s}$ amples $\mathrm{w}$ ere $\mathrm{s}$ imilar to the dimensions of the pristine samples (Fig. 5c). Refinement al so revealed that these samples cont ained 4.3(1) $\mathrm{w} \mathrm{t. \%} \mathrm{T} \mathrm{iC,} \mathrm{a} \mathrm{va} \mathrm{lue} \mathrm{low} \mathrm{er} \mathrm{th} \mathrm{an} \mathrm{in} \mathrm{the} \mathrm{pr} \mathrm{istine} \mathrm{s} \mathrm{amples.} \mathrm{Since} \mathrm{th} \mathrm{is} \mathrm{is} \mathrm{unl} \mathrm{ikely,} \mathrm{it} \mathrm{c} \mathrm{onfirms} \mathrm{the}$ somewhat inhomogeneous distribution of $\mathrm{TiC}$ in these samples.

While the a- and c-LPs for each MAX phase discussed above were distorted at LT conditions (Fig. 7), the a-LP for the TiC phase remained relatively constant at all conditions, showing at most an increase of $\sim 0.2 \%$ in the $\mathrm{Ti}_{3} \mathrm{AlC}_{2}$-LT samples (Table 1); while the $\mathrm{TiC}$ content increased in some cases, its LPs remained quite close to their values in the pristine samples.

Rietveld refinement of the $\mathrm{Ti}_{2} \mathrm{AlN}$ samples revealed a similar trend in distorted LPs (Figs. 6 and 7). The best fit, however, was achieve d when $\mathrm{TiN}$ and $\mathrm{Ti}_{4} \mathrm{AlN}_{3}$ were refined as well. $\mathrm{Ti}_{2} \mathrm{AlN}-\mathrm{LT}$ showed an increase in the c-LP from 13.640(2) to 13.714(4) $\AA$ and a decrease in a-LP from 2.9886(3) to 2.9808(6) $\AA$ (Figs. $6 \mathrm{a}$ and $\mathrm{b}$ and 7). Unsurprisingly, there was an increase in microstrain from $0.16 \%$ to $0.2 \%$ (Fig. $6 \mathrm{~b}$ and Table 1). At 13.664(4) $\AA$ and 3.0086(3) $\AA$, the c- and a-LPs, respectively, of the $\mathrm{Ti}_{2} \mathrm{AlN}-\mathrm{HT}$ samples $w$ ere $t$ he least dist orted of al 1 sam ples i rradiated to $360(20)^{\circ} \mathrm{C}$ (Fig. 7). At $0.58 \%$, the microstrain found in the $\mathrm{Ti}_{2} \mathrm{AlN}-\mathrm{HT}$ sample was significantly higher than all other samples irradiated at this condition. Unique a mong all MAX phases tested he rein, $\mathrm{Ti}_{2} \mathrm{AlN}-\mathrm{HT}$ re sulted in the formation of 36(3) wt. $\% \mathrm{Ti}_{4} \mathrm{AlN}_{3}$. An additional phase with peaks at $\sim 36,41$ and $58.6^{\circ} 2 \theta$ was unidentified, due to these peaks' low intensity and the high background noise.

It is also important to note that the relative atomic positions of each MAX phase tested herein did not change significantly under the studied irradiation conditions (Table 1). 
Post irradiation TEM analysis was completed for the $\mathrm{Ti}_{2} \mathrm{AlC}$ (Fig. 8) and $\mathrm{Ti}_{3} \mathrm{AlC}_{2}$ (Fig. 9) samples. TEM micrographs of $\mathrm{Ti}_{2} \mathrm{AlC}-\mathrm{LT}$ showed a large concentration of small black spots, on the order of $15 \mathrm{~nm}$ in size, with an areal density too large to quantify (Fig. 8a and b). SAED pa tterns from these regions showed a crystalline microstructure, with a n increased di ffuse ba ckground. TEM m icrographs of the $\mathrm{Ti}_{2} \mathrm{AlC}-\mathrm{HT}$ sample revealed the presence of dislocation loops with an average diameter of 51(21) nm, having an areal density of $7.7 \times 10^{13} \mathrm{~m}^{-2}$ (Fig. $8 \mathrm{c}$ and d). Seen edge on, the loops formed parallel to the basal planes and were arrayed coherently a long the [0001] direction within the $\mathrm{Ti}_{2} \mathrm{AlC}$ lattice. S AED patterns of the regions in Fig. $8 \mathrm{c}$ revealed that the $\mathrm{Ti}_{2} \mathrm{AlC}$ samples maintained their crystallinity when irradiated to $0.1 \mathrm{dpa}$ at $695(25)^{\circ} \mathrm{C}$.

Irradiation of the $\mathrm{Ti}_{3} \mathrm{AlC}_{2}$ samples at $\mathrm{LT}$ resulted in larger dislocation loops, with an average diameter of $75(25) \mathrm{nm}$ (Fig. 9a and b). Having an areal density of $1.2 \times 10^{14} \mathrm{~m}^{-2}$, the loops were randomly dispersed, and appear to lie within the (0001) habit plane. SAED patterns of the region shown in Fig. 9b revealed that the $\mathrm{Ti}_{3} \mathrm{AlC}_{2}$ samples also retain their crystallinity, though with a slightly diffuse background. The $\mathrm{Ti}_{3} \mathrm{AlC}_{2}-\mathrm{HT}$ samples formed triangular d efects $\mathrm{w}$ ith an av erage edge length of $27(7) \mathrm{nm}$ and areal density of $8.9 \times 10^{13} \mathrm{~m}^{-2}$, lying within the (0001) habit plane, as determined by S AED (Fig. 9c and d). The defect density decreased with increasing temperature for both $\mathrm{Ti}_{3} \mathrm{AlC}_{2}$ and $\mathrm{Ti}_{2} \mathrm{AlC}$. However, the formation of triangular defects appears to be unique to $\mathrm{Ti}_{3} \mathrm{AlC}_{2}$. The defect dimensions are summarized in Table 2.

The measured RT $\rho$ of the pristine MAX phases in this work compare well with those previously reported ( Table 2) [33-37]. After LT irra diation, the $\rho$ values were 4-10 times great er than be fore irradiation (Table 2). The largest increase in RT $\rho$ was seen in the $\mathrm{Ti}_{3} \mathrm{AlC}_{2}$ samples, with 2.84(2) $\mu \Omega \mathrm{m}$ after irradiated as compared to $0.262(8) \mu \Omega \mathrm{m}$ before. At 2.2(1) $\mu \Omega \mathrm{m}$, the $\mathrm{Ti}_{3} \mathrm{SiC}_{2}-\mathrm{CG}$ samples had a higher $\rho$ compared to $\mathrm{Ti}_{3} \mathrm{SiC}_{2}-\mathrm{FG}$, at 1.1(1) $\mu \Omega \mathrm{m}$, both of which increased from the pristine values of 
$0.21(1)$ and $0.21(1)$, respectively. The $\rho$ of the $\mathrm{Ti}_{2} \mathrm{AlN}$ samples increased from $0.37(1) \mu \Omega \mathrm{m}$ pristine to 1.46(1) $\mu \Omega \mathrm{m}$ a fter ir radiation at L T. At $0.75(1) \mu \Omega \mathrm{m}, \mathrm{Ti}_{2} \mathrm{AlC}$ yielded the lowest increase in $\rho$ compared to $0.31(4) \mu \Omega \mathrm{m}$ as pristine. In contradistinction to the low temperature irradiations, samples irradiated to $\mathrm{HT}$ experienced only a slight increase in $\rho$, ranging from $0.23(1)$ for $\mathrm{Ti}_{3} \mathrm{SiC}_{2}-\mathrm{FG}$ to $0.44(1)$ for $\mathrm{Ti}_{2} \mathrm{AlC}$ (Table 2).

\section{Discussion}

Rietveld refinement revealed a distortion of $\mathrm{LPs}$ under neutron irradiation of the $\mathrm{Ti}_{3} \mathrm{SiC}_{2}-\mathrm{FG}, \mathrm{Ti}_{3} \mathrm{SiC}_{2}-$ $\mathrm{CG}, \mathrm{Ti}_{3} \mathrm{AlC}_{2}, \mathrm{Ti}_{2} \mathrm{AlC}$ and $\mathrm{Ti}_{2} \mathrm{AlN}$ samples (Fig. 7). This result concurs with previous work where heavy ions and $\mathrm{He}$ i rradiations were shown to r esult in lattice distortions [11-16,18,19,21,23,24]. After LT irradiation, $\mathrm{Ti}_{3} \mathrm{AlC}_{2}$ and $\mathrm{Ti}_{2} \mathrm{AlC}$ s howed the 1 argest increase in $\mathrm{c}-\mathrm{LP}$, while $\mathrm{Ti}_{2} \mathrm{AlN}$ show ed the least (Fig. 7a). The a-LPs de creased after LT ir radiation, with $\mathrm{Ti}_{2} \mathrm{AlC}$ s howing the largest de viation from pristine (Fig. 7b). In contradistinction, after $\mathrm{H} \mathrm{T}$ irra diation, the $\mathrm{L}$ Ps for most $\mathrm{m}$ aterials te sted were distorted by $\leq 0.1 \%$, confirming the dynamic recovery capabilities of the MAX phases. There were little observable differences between the fine- and coarse-grained $\mathrm{Ti}_{3} \mathrm{SiC}_{2}$ samples, both of which showed less extensive distortion than $\mathrm{Ti}_{3} \mathrm{AlC}_{2}$.

What is noteworthy and completely unexpected, however, was the dissociation of $\sim 50 \mathrm{wt} . \%$ of the $\mathrm{Ti}_{3} \mathrm{AlC}_{2}$ into TiC. One of the reasons this was unexpected is that it was never observed or reported on in any of the heavy ion irradiation work $[11-16,18,19,21,23,24]$. This is an important result since it is clear that $\mathrm{Ti}_{3} \mathrm{AlC}_{2}$ may not be as resistant to neutrons as previously assumed. Clearly, the dissociation of $\mathrm{Ti}_{3} \mathrm{AlC}_{2}$ into $\mathrm{TiC}$ appears to be enhanced by the neutron irradiation, the extent of which increased at the lower irradiation temperature. The differences between charged particles and neutrons for irradiation are well known, each varying in energy range, penetration depth, volume of interaction and length of irradiation exposure [38]. The correlation between irradiation temperature and damage rate is also well 
known, allowing for comparison of various particles used for irradiation at a fixed dose, assuming a recombination dominant regime [39]. In this case, the solution for the correlation which assumes that the ratio of defects lost to sinks, $R_{\mathrm{s}}=N_{\mathrm{sv}} / N_{\mathrm{si}}$, is invariant is more accepted for comparing defect structures, shown by the following equation:

$$
T_{2}-T_{1}=\frac{\left(\frac{k T_{1}^{2}}{E_{m}^{v}+2 E_{f}^{v}}\right) \ln \left(\frac{\phi_{2}}{\phi_{1}}\right)}{1-\left(\frac{k T_{1}}{E_{m}^{v}+2 E_{f}^{v v}}\right) \ln \left(\frac{\phi_{2}}{\phi_{1}}\right)}
$$

where $E_{f}^{v}, E_{m}^{v}, \phi, T$ and $k$ are the energy of formation of a vacancy, energy of migration of a vacancy, damage rate in dpa $\mathrm{s}^{-1}$, irradiation temperature in $\mathrm{K}$ and Boltzmann's constant, respectively. Based on the irradiation dose rate herein, the damage rate for this study is assumed to be $4.7 \times 10^{-9} \mathrm{dpa} \mathrm{s}^{-1}$. As $\mathrm{Ti}_{3} \mathrm{AlC}_{2}$ dissociated into $\mathrm{TiC}$ by way of $\mathrm{Al}$ migration out of the layered structure, the correlation was calculated based on $\mathrm{Al}$ vacancies with $E_{\mathrm{f}}=4 \mathrm{eV}$ and $E_{\mathrm{m}}=0.61 \mathrm{eV}$, based on density functional theory calculations [40]. According to the dose rates reported in Ref. [15], the damage rate for $1 \mathrm{MeV} \mathrm{Xe}$ irradiation of $\mathrm{Ti}_{3} \mathrm{AlC}_{2}$ was $\sim 2.5 \times 10^{-3} \mathrm{dpa} \mathrm{s}^{-1}$, in good agreement with typical heavy ion irradiation studies [38]. The irradiation temperatures of the study herein were $360^{\circ} \mathrm{C}$ and $695^{\circ} \mathrm{C}$. Based on this alone, to expect similar defect structures at $0.1 \mathrm{dpa}$, heavy ion irradiation studies would need to be conducted at $\sim 420^{\circ} \mathrm{C}$ and $\sim 840^{\circ} \mathrm{C}$, respectively. This required increase in irradiation temperature could explain the lack of irradiation defects and phase decomposition shown in Ref. [15], which was conducted at room temperature. Such high-temperature ion irradiation studies were lacking in the literature. More work is required to better understand the correlations between these particles in relation to MAX phase irradiation, and high-temperature ion irradiation should more thoroughly be explored. Based on the results shown in Table 1, both the FG and CG- $\mathrm{Ti}_{3} \mathrm{SiC}_{2}$ samples showed a slight increase in TiC content when irradiated under LT conditions. Given the fluctuations in the TiC contents of the pristine and irradiated samples, it is difficult to conclude if any dissociation occurred at all. If it did 
occur, however, it is far less extensive than in the $\mathrm{Ti}_{3} \mathrm{AlC}_{2}$ case, and longer exposure times will clarify the issue.

Fig. 7 summarizes the effect of irradiation temperature on the LPs of each MAX phase tested herein. In all cases, irradiation at $\mathrm{LT}$ resulted in an expansion in the c-LP and a reduction in the a-LP. The $\mathrm{Ti}_{3} \mathrm{AlC}_{2}$ showed the largest increase in c-LP, with $\mathrm{Ti}_{2} \mathrm{AlN}$ showing the least. $\mathrm{Ti}_{2} \mathrm{AlC}$ had the largest reduction in a-LP, while the $\mathrm{Ti}_{3} \mathrm{SiC}_{2}$ samples had the least. Unsurprisingly, the $\mathrm{Ti}_{3} \mathrm{SiC}_{2}-\mathrm{FG}$ and $\mathrm{CG}$ samples responded similarly (Fig. 7). For most samples, irradiation at HT resulted in LPs that were only slightly distorted from pristine dimensions. $\mathrm{Ti}_{2} \mathrm{AlN}$ revealed an increase in a-LP at $\mathrm{HT}$, in contrast to all other samples tested. This is attributed to the extensive distortion observed in the XRD spectrum (Fig. 6c) seen by the increased background intensity, and the formation of several impurity phases after irradiation.

In sharp contrast, $\mathrm{Ti}_{2} \mathrm{AlC}$ showed superb resistance to lattice distortions and/or dissociation. It is unclear at this time why $\mathrm{Ti}_{2} \mathrm{AlC}$ is so much more stable vis-à-vis dissociation than $\mathrm{Ti}_{3} \mathrm{AlC}_{2}$. While $\mathrm{XRD}$ results confirmed the phase content for the samples tested, the question remains as to the fate of the $\mathrm{Al}$ and $\mathrm{Si}$ content in the cases where $\mathrm{TiC}$ and $\mathrm{TiN}$ were formed.

Also of note is the resiliency of $\mathrm{TiC}$ a fter irradiation at these conditions. While $\mathrm{Ti}_{3} \mathrm{AlC}_{2}$ and $\mathrm{Ti}_{2} \mathrm{AlC}$ samples showed significant lattice distortion after L T irra diation, the a-LP of the TiC phase remained largely unperturbed, at most increasing by $0.19 \%$ in the $\mathrm{Ti}_{3} \mathrm{AlC}_{2}$ samples. It is plausible then that the $\mathrm{TiC}$ which forms via dissociation of $\mathrm{Ti}_{3} \mathrm{AlC}_{2}$ relieves the lattice strains. Note that the removal of the Allayer w ould re sult in the de-twinning of the $\mathrm{Ti}_{6} \mathrm{C}$ octahedra layers, forming bulk $\mathrm{TiC}$ [41]. While the large scale dissociation of $\mathrm{Ti}_{3} \mathrm{AlC}_{2}$ into $\mathrm{TiC}$ may be detrimental to its future in nuclear applications, it is unclear if the presence of s mall vol ume fractions w ill be problematic for ot her MAX pha ses, since 
commercially available $\mathrm{Ti}_{2} \mathrm{AlC}$ a nd $\mathrm{Ti}_{3} \mathrm{SiC}_{2}$ often contain $\sim 10$ wt. $\% \mathrm{TiC}$. More work is $\mathrm{n}$ eeded to ascertain the extent of influence the TiC impurity has on the irradiated properties of the MAX phases. The collision of high-energy neutrons with lattice atoms is known to create point defects, increase the dangling bo nd de nsity and result in an increase in resistivity [42]. Post-irradiation RT $\rho$ values of samples irradiated at LT conditions were found to be almost an order of magnitude higher than seen for pristine samples ( Table 2), c onfirming that L T neutron irradiation ge nerated a significant a mount of point defects. After irradiation, $\mathrm{Ti}_{3} \mathrm{AlC}_{2}$ possessed the highest $\mathrm{RT} \rho$ at 2.84(2) $\mu \Omega \mathrm{m}$. TEM was used to confirm the increase in defect density as a result of neutron irradiation of Ti $\mathrm{i}_{2} \mathrm{AlC}$ (Fig. 8) and $\mathrm{Ti}_{3} \mathrm{AlC}_{2}$ (Fig. 9). The majority of the dislocation loops were seen to form in the basal planes of the MAX phases (Figs. 8c and d and 9).

With increasing temperatures, if the defect mobility is high enough, they can start to agglomerate and/or annihilate. Dislocation loops a re a lso know $\mathrm{n} t \mathrm{o}$ i nteract a nd $\mathrm{c}$ oalesce i nto f ewer but 1 arger defect structures with increasing temperatures [38]. Annihilation of the point defects reduces the dangling bond density, resulting in a decrease in resistivity. This was confirmed herein for all HT samples; all showed only a slight increase in RT $\rho$ (Table 2) compared to their $\rho$ values prior to irradiation. HT irradiation resulted in the agglomeration of the small de fect clusters seen in the $\mathrm{Ti}_{2} \mathrm{AlC}-\mathrm{LT}$ sample (Fig. 8a) into larger dislocation loop structures (Fig. 8c and d). The dislocation loops seen in the $\mathrm{Ti}_{3} \mathrm{AlC}_{2}$ sample at $\mathrm{LT}$

(Fig. 9a and b) were not observed at HT, where instead, triangular defects were identified (Fig. 9c and d). Further TEM of all samples is ongoing and is the focus of a future study.

\section{Summary and conclusions}

The first ever reported neutron irradiation of bulk MAX phases show that $\mathrm{Ti}_{3} \mathrm{SiC}_{2}, \mathrm{Ti}_{3} \mathrm{AlC}_{2}, \mathrm{Ti}_{2} \mathrm{AlC}$ and $\mathrm{Ti}_{2} \mathrm{AlN} \mathrm{r}$ emain f ully c rystalline un der ne utron i rradiation up to $0.1 \mathrm{dpa}$ at $360(20)$ a nd $695(25)^{\circ} \mathrm{C}$. However, Rietveld analysis of the XRD spectra for $\mathrm{Ti}_{2} \mathrm{AlC}$ and $\mathrm{Ti}_{3} \mathrm{AlC}_{2}$ reveal a drastic difference in 
irradiation tolerance be tween $\mathrm{t}$ he $\mathrm{t}$ wo $\mathrm{c}$ ompounds. $\mathrm{R}$ oughly $50 \mathrm{w}$ t.\% of $\mathrm{t}$ he $\mathrm{T}_{3} \mathrm{AlC}_{2}$ sample $\mathrm{w}$ as converted to TiC with a $1.7 \%$ increase in c-LP and a $0.6 \%$ decrease in a-LP after LT irradiation (Fig. 7). This dissoc iation $\mathrm{w}$ as not mitigated by $\mathrm{i}$ rradiation at $\mathrm{H} \mathrm{T}$, though the 1 attice pa rameters s howed 1 ess distortion, being close to pristine. This same trend in lattice parameters is seen in $\mathrm{Ti}_{2} \mathrm{AlC}$; however, the extent of dissociation into $\mathrm{TiC}$ is not observed. $\mathrm{Ti}_{2} \mathrm{AlN}$ was seen to dissociate into $13(1) \mathrm{wt} . \% \mathrm{TiN}$ and 36(3) wt.\% $\mathrm{Ti}_{4} \mathrm{AlN}_{3}$, resulting in significant lattice strains after irradiation at $\mathrm{HT}$.

$\mathrm{Ti}_{3} \mathrm{SiC}_{2}$ also show ed lattice dis tortion, but to a lesser ex tent than $\mathrm{Ti}_{3} \mathrm{AlC}_{2}$ or $\mathrm{Ti}_{2} \mathrm{AlC}$, with only $\sim 1 \%$ increase in c-LP and $0.6 \%$ decrease in a-LP. The Ti-Si bonding has been shown to be stronger than TiAl bonding in the MAX phases, which could explain the lesser distortion of the lattice [43]. There also appears to be no difference in the lattice response as a function of grain size.

Neutron irradiation resulted in the formation of dislocation loops in $\mathrm{Ti}_{2} \mathrm{AlC}$ and $\mathrm{Ti}_{3} \mathrm{AlC}_{2}$. In the former, irradiation at LT resulted in a high density of small dislocation loops on the order of $15 \mathrm{~nm}$. Irradiation at $\mathrm{HT}$ resulted in agglomerated basal plane loops that grew to a size of 51(21) nm (Fig. 4c). In $\mathrm{Ti}_{3} \mathrm{AlC}_{2}$, loops of 75(25) $\mathrm{nm}$ are seen after irradiation at LT, while triangular defects with edge lengths $27(7) \mathrm{nm}$ form after irradiation at HT.

RT $\rho$ measurements of $\mathrm{Ti}_{3} \mathrm{SiC}_{2}, \mathrm{Ti}_{3} \mathrm{AlC}_{2}, \mathrm{Ti}_{2} \mathrm{AlC}$ and $\mathrm{Ti}_{2} \mathrm{AlN}$ show an order of magnitude increase in resistivity at $\mathrm{LT}$, but only a $25 \%$ increase at $\mathrm{HT}$. The low resistivity values of samples irradiated $\mathrm{HT}$ is strong e vidence for the M AX pha ses' dyna mic r ecovery at temperatures as 1 ow at $695(25)^{\circ} \mathrm{C}$. TEM micrographs of the defects formed in $\mathrm{Ti}_{2} \mathrm{AlC}$ and $\mathrm{Ti}_{3} \mathrm{AlC}_{2}$ correlate the effect irradiation temperature on the resistivity values. At 2.2(1) $\mu \Omega \mathrm{m}$, the $\mathrm{RT} \rho$ of $\mathrm{Ti}_{3} \mathrm{SiC}_{2}-\mathrm{CG}$ was twice that of $\mathrm{Ti}_{3} \mathrm{SiC}_{2}-\mathrm{FG}$, which is attributed to the increase in grain boundary fraction present in the fine grained samples, likely resulting in fewer residual defects after irradiation. While defects are known to annihilate at grain boundary sinks, 
more TEM analysis is required to quantify the effect of de creased grain size on defect formation for $\mathrm{Ti}_{3} \mathrm{SiC}_{2}$.

Also of note is the difference in defect microstructure seen in this work compared to previous heavy ion and He studies. This work shows evidence for dislocation loops that have not been previously reported on in the MAX phases. Work is ongoing to fully characterize the defect microstructures, as more data at increasing dosage are compiled.

\section{Acknowledgements}

This work is funded by the Department of Energy's Nuclear Energy University Program (DOE-NEUP). The a uthors w ould like to thank Dr David Carpenter of MIT for his a ssistance with irradiations and fluence calculations for the irradiated samples. The authors would also like to thank Mike Tosten, Gregg Creech, and David Missimer of SRNL for their help with characterizing the irradiated samples.

\section{References}

[1] DOE US. A Technology Roadmap for Generation IV Nuclear Energy Systems. In: Forum USDNERACatGII, editor, 2002.

[2] Barsoum MW. The $\mathrm{M}_{n+1} \mathrm{AX}_{\mathrm{n}}$ phases and their properties. In: Riedel R, Chen I-W, editors. Ceramics Science and Technology. Weinheim: Wiley-VCH; 2010. p. 299.

[3] Radovic M, Barsoum MW, El-Raghy T, Seidensticker J, Wiederhorn S, Tensile properties of $\mathrm{Ti}_{3} \mathrm{SiC}_{2}$ in the $25-1300^{\circ} \mathrm{C}$ temperature range, Acta Materialia 2000;48:453.

[4] Radovic M, Barsoum MW, El-Raghy T, Wiederhorn SM, Luecke WE, Effect of temperature, strain rate and grain size on the mechanical response of $\mathrm{Ti}_{3} \mathrm{SiC}_{2}$ in tension, Acta Materialia 2002;50:1297. 
[5] Barsoum MW, Radovic M. Mechanical properties of the MAX phases. In: Buschow KHJ, Robert WC, Merton CF, Bernard I, Edward JK, Subhash M, Patrick V, editors. Encyclopedia of Materials: Science and Technology. Oxford: Elsevier, 2004. p. 1.

[6] Barsoum MW. MAX Phases: properties of machinable carbides and nitrides. Weinheim: Wiley VCH; 2013.

[7] Tallman DJ, Anasori B, Barsoum MW, A critical review of the oxidation of $\mathrm{Ti}_{2} \mathrm{AlC}, \mathrm{Ti}_{3} \mathrm{AlC}_{2}$ and $\mathrm{Cr}_{2} \mathrm{AlC}$ in air, Materials Research Letters 2013;1:115.

[8] Basu S, Obando N, Gowdy A, Karaman I, Radovic M, Long-term oxidation of Ti ${ }_{2} \mathrm{AlC}$ in air and water vapor at $1000-1300^{\circ} \mathrm{C}$ temperature range, J. Electrochem. Soc. 2012;159:C90.

[9] Cui B, Jayaseelan DD, Lee WE, Microstructural evolution during high-temperature oxidation of $\mathrm{Ti}_{2} \mathrm{AlC}$ ceramics, Acta Materialia 2011;59:4116.

[10] Song GM, Pei YT, Sloof WG, Li SB, De Hosson JTM, van der Zwaag S, Oxidation-induced crack healing in $\mathrm{Ti}_{3} \mathrm{AlC}_{2}$ ceramics, Scripta Mater. 2008; 58:13.

[11] Nappé JC, Grosseau P, Audubert F, Guilhot B, Beauvy M, Benabdesselam M, Monnet I, Damages induced by heavy ions in titanium silicon carbide: effects of nuclear and electronic interactions at room temperature, Journal of Nuclear Materials 2009;385:304.

[12] Nappé JC, Maurice C, Grosseau P, Audubert F, Thomé L, Guilhot B, Beauvy M, Benabdesselam M, Microstructural changes induced by low energy heavy ion irradiation in titanium silicon carbide, Journal of the European Ceramic Society 2011;31:1503.

[13] Nappé JC, Monnet I, Audubert F, Grosseau P, Beauvy M, Benabdesselam M, Formation of nanosized hills on $\mathrm{Ti}_{3} \mathrm{SiC}_{2}$ oxide layer irradiated with swift heavy ions, Nucl Instrum Meth B $2012 ; 270: 36$. 
[14] Nappé JC, Monnet I, Grosseau P, Audubert F, Guilhot B, Beauvy M, Benabdesselam M, Thome L, Structural changes induced by heavy ion irradiation in titanium silicon carbide, Journal of Nuclear Materials 2011;409:53.

[15] Whittle KR, Blackford MG, Aughterson RD, Moricca S, Lumpkin GR, Riley DP, Zaluzec NJ, Radiation tolerance of $\mathrm{M}_{\mathrm{n}+1} \mathrm{AX}$ phases, $\mathrm{Ti}_{3} \mathrm{AlC}_{2}$ and $\mathrm{Ti}_{3} \mathrm{SiC}_{2}$, Acta Materialia 2010;58:4362.

[16] Liu XM, Le Flem M, Béchade JL, Monnet I, Nanoindentation investigation of heavy ion irradiated $\mathrm{Ti}_{3}(\mathrm{Si}, \mathrm{Al}) \mathrm{C}_{2}$, Journal of Nuclear Materials 2010;401:149.

[17] Liu XM, Le Flem M, Bechade JL, Onimus F, Cozzika T, Monnet I, XRD investigation of ion irradiated $\mathrm{Ti}_{3} \mathrm{Si}_{0.90} \mathrm{Al}_{0.10} \mathrm{C}_{2}$, Nucl Instrum Meth B 2010;268:506.

[18] Le Flem M, Liu X, Doriot S, Cozzika T, Monnet I, Irradiation damage in $\mathrm{Ti}_{3}\left(\mathrm{Si}_{1} \mathrm{Al}\right) \mathrm{C}_{2}$ : a TEM investigation, International Journal of Applied Ceramic Technology 2010;7:766.

[19] Le Flem M, Monnet I, Saturation of irradiation damage in $(\mathrm{Ti}, \mathrm{Zr})_{3}(\mathrm{Si}, \mathrm{Al}) \mathrm{C}_{2}$ compounds, Journal of Nuclear Materials 2013;433:534.

[20] Zhang L, Qi Q, Shi LQ, O’Connor DJ, King BV, Kisi EH, Venkatachalam DK, Damage tolerance of $\mathrm{Ti}_{3} \mathrm{SiC}_{2}$ to high energy iodine irradiation, Applied Surface Science 2012;258:6281. [21] Bugnet M, Cabioc'h T, Mauchamp V, Guérin P, Marteau M, Jaouen M, Stability of the nitrogendeficient $\mathrm{Ti}_{2} \mathrm{AlN}_{\mathrm{x}}$ MAX phase in $\mathrm{Ar}^{2+}$-irradiated $(\mathrm{Ti}, \mathrm{Al}) \mathrm{N} / \mathrm{Ti}_{2} \mathrm{AlN}_{\mathrm{x}}$ multilayers, J Mater Sci 2010;45:5547.

[22] Xiao J, Wang C, Yang T, Kong S, Xue J, Wang Y, Theoretical investigation on helium incorporation in $\mathrm{Ti}_{3} \mathrm{AlC}_{2}$, Nuclear Instruments and Methods in Physics Research Section B: Beam Interactions with Materials and Atoms 2013;304:27. 
[23] Wang C, Yang T, Kong S, Xiao J, Xue J, Wang Q, Hu C, Huang Q, Wang Y, Effects of He irradiation on $\mathrm{Ti}_{3} \mathrm{AlC}_{2}$ : damage evolution and behavior of He bubbles, Journal of Nuclear Materials 2013;440:606.

[24] Patel MK, Tallman DJ, Valdez JA, Aguiar J, Anderoglu O, Tang M, Griggs J, Fu E, Wang Y, Barsoum MW, Effect of helium irradiation on $\mathrm{Ti}_{3} \mathrm{AlC}_{2}$ at $500^{\circ} \mathrm{C}$, Scripta Materialia 2014;77:1.

[25] Yang T, Wang C, Taylor CA, Huang X, Huang Q, Li F, Shen L, Zhou X, Xue J, Yan S, Wang Y, The structural transitions of $\mathrm{Ti}_{3} \mathrm{AlC}_{2}$ induced by ion irradiation, Acta Materialia 2014;65:351.

[26] Hoffman EN, Vinson DW, Sindelar RL, Tallman DJ, Kohse G, Barsoum MW, MAX phase carbides and nitrides: properties for future nuclear power plant in-core applications and neutron transmutation analysis, Nuclear Engineering and Design 2012;244:17.

[27] Barsoum M, El-Raghy T, Ali M, Processing and characterization of $\mathrm{Ti}_{2} \mathrm{AlC}$, $\mathrm{Ti}_{2} \mathrm{AlN}$, and $\mathrm{Ti}_{2} \mathrm{AlC}_{0.5} \mathrm{~N}_{0.5}$, Metallurgical and Materials Transactions A 2000;31:1857.

[28] Heinisch HL, Greenwood LR, Weber WJ, Williford RE, Displacement damage in silicon carbide irradiated in fission reactors, Journal of Nuclear Materials 2004;327:175.

[29] Carpenter DM. An assessment of silicon carbide as a cladding material for light water reactors. Massachusetts Institute of Technology, 2010.

[30] Rodríguez-Carvajal J, Recent advances in magnetic structure determination by neutron powder diffraction, Physica B: Condensed Matter 1993;192:55.

[31] Rietveld H, A profile refinement method for nuclear and magnetic structures, J Appl Crystallogr $1969 ; 2: 65$

[32] Rodriguez-Carvajal J, Fernandez-Diaz MT, Martinez JL, Neutron diffraction study on structural and magnetic properties of $\mathrm{La}_{2} \mathrm{NiO}_{4}$, Journal of Physics: Condensed Matter 1991;3. 
[33] Barsoum MW, Yoo HI, Polushina IK, Rud' VY, Rud' YV, El-Raghy T, Electrical conductivity, thermopower, and Hall effect of $\mathrm{Ti}_{3} \mathrm{AlC}_{2}, \mathrm{Ti}_{4} \mathrm{AlN}_{3}$, and $\mathrm{Ti}_{3} \mathrm{SiC}_{2}$, Physical Review B 2000;62:10194.

[34] Scabarozi T, Ganguly A, Hettinger JD, Lofland SE, Amini S, Finkel P, El-Raghy T, Barsoum MW, Electronic and thermal properties of $\operatorname{Ti}_{3} \mathrm{Al}\left(\mathrm{C}_{0.5} \mathrm{~N}_{0.5}\right)_{2}, \mathrm{Ti}_{2} \mathrm{Al}\left(\mathrm{C}_{0.5} \mathrm{~N}_{0.5}\right)$, and $\mathrm{Ti}_{2} \mathrm{AlN}$, Journal of Applied Physics 2008;104:073713.

[35] Finkel P, Hettinger JD, Lofland SE, Barsoum MW, El-Raghy T, Magnetotransport properties of the ternary carbide $\mathrm{Ti}_{3} \mathrm{SiC}_{2}$ : Hall effect, magnetoresistance, and magnetic susceptibility, Physical Review B 2001;65:035113.

[36] Wang XH, Zhou YC, Microstructure and properties of $\mathrm{Ti}_{3} \mathrm{AlC}_{2}$ prepared by the solid-liquid reaction synthesis and simultaneous in-situ hot pressing process, Acta Materialia 2002;50:3143.

[37] Wang P, Mei B-c, Hong X-l, Zhou W-b, Synthesis of $\mathrm{Ti}_{2} \mathrm{AlC}$ by hot pressing and its mechanical and electrical properties, Transactions of Nonferrous Metals Society of China 2007;17:1001.

[38] Was GS. Fundamentals of Radiation Materials Science: Metals and Alloys. Berlin: Springer; 2007.

[39] Mansur LK, Void swelling in metals and alloys under irradiation: an assessment of the theory, Nuclear Technology 1978;40:5.

[40] Middleburgh SC, Lumpkin GR, Riley D, Accommodation, accumulation, and migration of defects in $\mathrm{Ti}_{3} \mathrm{SiC}_{2}$ and $\mathrm{Ti}_{3} \mathrm{AlC}_{2}$ MAX phases, Journal of the American Ceramic Society 2013:n/a.

[41] Barsoum M, El'Raghy T, Farber L, Amer M, Christini R, Adams A, The Topotactic Transformation of $\mathrm{Ti}_{3} \mathrm{SiC}_{2}$ into a Partially Ordered Cubic $\mathrm{Ti}\left(\mathrm{C}_{0.67} \mathrm{Si}_{0.06}\right)$ Phase by the Diffusion of $\mathrm{Si}$ into Molten Cryolite, Journal of The Electrochemical Society 1999;146:3919.

[42] Snead LL, Limits on irradiation-induced thermal conductivity and electrical resistivity in silicon carbide materials, Journal of Nuclear Materials 2004;329-333, Part A:524. 
[43] Magnuson M, Palmquist JP, Mattesini M, Li S, Ahuja R, Eriksson O, Emmerlich J, Wilhelmsson O, Eklund P, Högberg H, Hultman L, Jansson U, Electronic structure investigation of $\mathrm{Ti}_{3} \mathrm{AlC}_{2}, \mathrm{Ti}_{3} \mathrm{SiC}_{2}$, and $\mathrm{Ti}_{3} \mathrm{GeC}_{2}$ by soft x-ray emission spectroscopy, Physical Review B 2005;72:245101.

Figure Captions

Fig. 1. Representative optical micrographs of (a) $\mathrm{Ti}_{2} \mathrm{AlC}$, (b) $\mathrm{Ti}_{3} \mathrm{AlC}_{2}$, (c) $\mathrm{Ti}_{2} \mathrm{AlN}$, (d) $\mathrm{Ti}_{3} \mathrm{SiC}_{2} \mathrm{FG}$ and (e) $\mathrm{Ti}_{3} \mathrm{SiC}_{2} \mathrm{CG}$ microstructures after etching with a solution of hydrofluoric acid, nitric acid and water. The MAX phase samples were fully dense and predominately single phase, with randomly aligned platelike grains, which are vibrantly colored after etching. TiC appears as bright white grains, denoted by white arrows.

Fig. 2. Rietveld analysis of $X R D$ data of (a) pristine $\mathrm{Ti}_{3} \mathrm{SiC}_{2}-\mathrm{FG}$, and $\mathrm{Ti}_{3} \mathrm{SiC}_{2}-\mathrm{FG}$ irradiated to (b) 0.1 dpa at $360(20)^{\circ} \mathrm{C}$ and (c) $0.1 \mathrm{dpa}$ at $695(25)^{\circ} \mathrm{C}$. Open circles, solid line and solid line at the bottom represent the observed data, calculated model and the difference between the two, respectively. The two rows of vertical tags represent the calculated Bragg reflections' positions of the $\mathrm{Ti}_{3} \mathrm{SiC}_{2}-\mathrm{FG}$ (first row), TiC (second). The large amorphous background was due to the mounting putty.

Fig. 3. Rietveld analysis of $\mathrm{XRD}$ data of (a) pristine $\mathrm{Ti}_{3} \mathrm{SiC}_{2}-\mathrm{CG}$, and $\mathrm{Ti}_{3} \mathrm{SiC}_{2}-\mathrm{CG}$ irradiated to (b) 0.1 dpa at $360(20)^{\circ} \mathrm{C}$ and (c) $0.1 \mathrm{dpa}$ at $695(25)^{\circ} \mathrm{C}$. Open circles, solid line and solid line at the bottom, represent the observed data, calculated model and the difference between the two, respectively. The two rows of vertical tags represent the calculated Bragg reflections' positions of the $\mathrm{Ti}_{3} \mathrm{SiC}_{2}$ (first row), $\mathrm{TiC}$ (second). The large amorphous background was due to the mounting putty.

Fig. 4. Rietveld analysis of XRD data of (a) pristine $\mathrm{Ti}_{3} \mathrm{AlC}_{2}, \mathrm{Ti}_{3} \mathrm{AlC}_{2}$ irradiated to (b) 0.1 dpa at $360(20)^{\circ} \mathrm{C}$ and (c) $0.1 \mathrm{dpa}$ at $695(25)^{\circ} \mathrm{C}$. Open circles, solid line and solid line at the bottom represent the observed data, calculated model and variance between the two, respectively. The two rows of vertical tags represent the calculated Bragg reflections' positions of the $\mathrm{Ti}_{3} \mathrm{AlC}_{2}$ (first row), $\mathrm{TiC}$ 
(second). The large amorphous background was due to the mounting putty. Where peaks were not present, sections were excluded from analysis (shown in gray).

Fig. 5. Rietveld analysis of XRD data of (a) pristine $\mathrm{Ti}_{2} \mathrm{AlC}$, and $\mathrm{Ti}_{2} \mathrm{AlC}$ irradiated to (b) $0.1 \mathrm{dpa}$ at $360(20)^{\circ} \mathrm{C}$ and (c) $0.1 \mathrm{dpa}$ at $695(25)^{\circ} \mathrm{C}$. Open circles, solid line and solid line at the bottom represent the observed data, calculated model and the difference between the two, respectively. The two rows of vertical tags represent the calculated Bragg reflections' positions of the $\mathrm{Ti}_{2} \mathrm{AlC}$ (first row), $\mathrm{TiC}$ (second). The large amorphous background was due to the mounting putty. Where peaks were not present, sections were excluded from analysis (shown in gray).

Fig. 6. Rietveld analysis of XRD data of (a) pristine $\mathrm{Ti}_{2} \mathrm{AlN}$, and $\mathrm{Ti}_{2} \mathrm{AlN}$ irradiated to (b) 0.1 dpa at $360(20)^{\circ} \mathrm{C}$ and (c) $0.1 \mathrm{dpa}$ at $695(25)^{\circ} \mathrm{C}$. Open circles, solid line and solid line at the bottom represent the observed data, calculated model and the difference between the two, respectively. The two rows of vertical tags represent the calculated Bragg reflections' positions of the $\mathrm{Ti}_{2} \mathrm{AlN}$ (first row), TiN (second). In (c), the best fit for $\mathrm{Ti}_{2} \mathrm{AlN}-\mathrm{HT}$ was achieved my including $\mathrm{Ti}_{4} \mathrm{AlN}_{3}$ in the refinement (third row). Dissociation of the parent $\mathrm{Ti}_{2} \mathrm{AlN}$ phase resulted in the formation of $\mathrm{TiN}^{\mathrm{N}}$ and $\mathrm{Ti}_{4} \mathrm{AlN}_{3}$. Peaks at $\sim 36,41$ and $58.6^{\circ} 2 \theta$ were unidentified due to their low intensity and the high background noise. The large amorphous background was due to the mounting putty.

Fig. 7. Plots comparing (a) c-LPs and (b) a-LPs as a function of irradiation temperature for the MAX phases $\mathrm{Ti}_{3} \mathrm{SiC}_{2}-\mathrm{FG}$ and $-\mathrm{CG}, \mathrm{Ti}_{3} \mathrm{AlC}_{2}, \mathrm{Ti}_{2} \mathrm{AlC}$ and $\mathrm{Ti}_{2} \mathrm{AlN}$ show a significant temperature dependence on irradiation-induced lattice deformation after low dose irradiation ( $0.1 \mathrm{dpa})$. Pristine values are plotted for reference. (a) $\mathrm{Ti}_{3} \mathrm{AlC}_{2}$ showed the highest expansion in c-LP at $360(20)^{\circ} \mathrm{C}$ irradiation, while $\mathrm{Ti}_{2} \mathrm{AlN}$ was least expanded. In all cases, the c-LP was close to that of the pristine lattice when irradiated at $695(25)^{\circ} \mathrm{C}$. (b) The a-LPs decreased with irradiation at $360(20)^{\circ} \mathrm{C}$, with $\mathrm{Ti}_{2} \mathrm{AlC}$ showing the most distortion. There appears to be no effect due to grain size with $\mathrm{Ti}_{3} \mathrm{SiC}_{2}$. Similarly to the c-LP, irradiation 
at $695(25)^{\circ} \mathrm{C}$ resulted in a-LPs that were close to that of the pristine sample. $\mathrm{Ti}_{2} \mathrm{AlN}$, however, showed an increase in a-LP after irradiation at $695(25)^{\circ} \mathrm{C}$.

Fig. 8. Bright field TEM micrographs of $\mathrm{Ti}_{2} \mathrm{AlC}$ (a) irradiated to $0.1 \mathrm{dpa}$ at $360(20)^{\circ} \mathrm{C}$ on the $(11-20)$ zone axis showing a large density of small defect clusters or loops on the order of $15 \mathrm{~nm}$. (b) The same region as (a) tilted off zone for two beam kinematic where the defects become invisible. (c, d) Bright field TEM micrographs of two regions of $\mathrm{Ti}_{2} \mathrm{AlC}$ irradiated to 0.1 dpa at $695(25)^{\circ} \mathrm{C}$, resulting in larger dislocation loops of 51(21) $\mathrm{nm}$ agglomerating in ordered arrays along the c lattice forming parallel to the basal plane. SAED patterns from these regions (insets) reveal that the MAX samples maintain crystallinity, with an increased diffuse background in the $360(20)^{\circ} \mathrm{C}$ samples, indicating increased disorder.

Fig. 9. Bright field TEM micrographs of $\mathrm{Ti}_{3} \mathrm{AlC}_{2}$ irradiated to $0.1 \mathrm{dpa}$ at $360(20)^{\circ} \mathrm{C}$ : (a) tilted off zone near (11-20) zone axis and (b) tilted to two beam kinematic condition near (0001) zone axis where dislocation loops of 75(25) nm appear to lie in the (0001) habit plane. Bright field TEM micrographs of a region in the $\mathrm{Ti}_{3} \mathrm{AlC}_{2}$ sample irradiated to $0.1 \mathrm{dpa}$ at $695(25)^{\circ} \mathrm{C}$. (c) Tilted to the $(0001)$ zone axis, and (b) the same region off zone for two beam kinematic condition reveal the formation of triangular defects with edge length $27(7) \mathrm{nm}$ forming on the basal plane. SAED patterns from these regions (insets) reveal that the MAX samples maintain crystallinity, with an increased diffuse background in the $360(20)^{\circ} \mathrm{C}$ samples, indicating increased disorder.

Table 1

Irradiation-induced structural and compositional changes in $\mathrm{Ti}_{3} \mathrm{SiC}_{2} \mathrm{FG}, \mathrm{Ti}_{3} \mathrm{SiC}_{2} \mathrm{CG}, \mathrm{Ti}_{3} \mathrm{AlC}_{2}, \mathrm{Ti}_{2} \mathrm{AlC}$ and $\mathrm{Ti}_{2} \mathrm{AlN}$ for irradiation up to $0.1 \mathrm{dpa}$ at $360(20)^{\circ} \mathrm{C}(\mathrm{LD}-\mathrm{LT})$ and at $695(25)^{\circ} \mathrm{C}(\mathrm{LD}-\mathrm{HT})$

\begin{tabular}{|l|c|c|c|c|c|c|c|c|c|}
\hline Condition & $\chi^{2}$ & a-LP $(\AA)$ & c-LP $(\AA)$ & Ti $_{\text {II_z }}$ & $\mathrm{C}_{-} \mathrm{z}$ & $\mathrm{TiC}$ & $\mathrm{TiC}$ a- & FWHM & $\mu \varepsilon \%$ \\
\hline
\end{tabular}




\begin{tabular}{|c|c|c|c|c|c|c|c|c|c|}
\hline & & & & position & position & $\begin{array}{l}\text { content } \\
\text { (wt.\%) }\end{array}$ & LP $(\AA)$ & $\begin{array}{c}\text { Parameter, } \\
U\end{array}$ & \\
\hline $\begin{array}{c}\mathrm{Ti}_{3} \mathrm{SiC}_{2} \mathrm{FG}- \\
\text { pristine }\end{array}$ & 16.4 & $\begin{array}{c}3.0668(7 \\
)\end{array}$ & $17.669(6)$ & $0.3652(5)$ & $0.569(2)$ & $20.0(5)$ & $\begin{array}{c}4.3186(1 \\
)\end{array}$ & $0.0051(3)$ & - \\
\hline $\begin{array}{c}\mathrm{Ti}_{3} \mathrm{SiC}_{2} \mathrm{FG}- \\
\mathrm{LD}-\mathrm{LT}\end{array}$ & 3.08 & $\begin{array}{c}3.0648(1 \\
)\end{array}$ & $17.812(9)$ & $0.3661(3)$ & $0.571(1)$ & $22.7(5)$ & $\begin{array}{c}4.3192(1 \\
)\end{array}$ & $0.0385(7)$ & 0.27 \\
\hline $\begin{array}{c}\mathrm{Ti}_{3} \mathrm{SiC}_{2} \mathrm{FG}- \\
\mathrm{LD}-\mathrm{HT}\end{array}$ & 1.83 & $\begin{array}{c}3.0667(2 \\
)\end{array}$ & $17.675(1)$ & $0.3675(7)$ & $0.556(3)$ & $25(1)$ & $\begin{array}{c}4.3195(2 \\
)\end{array}$ & $0.0133(5)$ & - \\
\hline $\begin{array}{c}\mathrm{Ti}_{3} \mathrm{SiC}_{2} \mathrm{CG}- \\
\text { pristine }\end{array}$ & 16.7 & $\begin{array}{c}3.0688(7 \\
)\end{array}$ & $17.680(1)$ & $0.3662(4)$ & $0.572(2)$ & $18.2(5)$ & $\begin{array}{c}4.3185(1 \\
)\end{array}$ & $0.0042(1)$ & - \\
\hline $\begin{array}{c}\mathrm{Ti}_{3} \mathrm{SiC}_{2} \mathrm{CG}- \\
\mathrm{LD}-\mathrm{LT}\end{array}$ & 1.84 & $\begin{array}{c}3.0647(1 \\
)\end{array}$ & $17.840(1)$ & $0.3664(3)$ & $0.565(1)$ & $23.3(5)$ & $\begin{array}{c}4.3238(2 \\
)\end{array}$ & $0.0488(1)$ & 0.33 \\
\hline $\begin{array}{c}\mathrm{Ti}_{3} \mathrm{SiC}_{2} \mathrm{CG}- \\
\mathrm{LD}-\mathrm{HT}\end{array}$ & 2.79 & $\begin{array}{c}3.0674(8 \\
)\end{array}$ & $17.669(1)$ & $0.3660(4)$ & $0.556(2)$ & $17.0(4)$ & $\begin{array}{c}4.3235(2 \\
)\end{array}$ & $0.0150(2)$ & 0.06 \\
\hline $\begin{array}{l}\mathrm{Ti}_{3} \mathrm{AlC}_{2-} \\
\text { pristine }\end{array}$ & 1.88 & $\begin{array}{c}3.0736(2 \\
)\end{array}$ & $18.562(2)$ & $0.1291(5)$ & $0.564(2)$ & $1.9(6)$ & $\begin{array}{c}4.3114(2 \\
)\end{array}$ & $0.0094(7)$ & 0.10 \\
\hline $\begin{array}{c}\mathrm{Ti}_{3} \mathrm{AlC}_{2} \text {-LD- } \\
\mathrm{LT}\end{array}$ & 2.63 & $\begin{array}{c}3.0542(2 \\
)\end{array}$ & $18.896(1)$ & $0.1251(3)$ & $0.648(1)$ & $52.6(9)$ & $\begin{array}{c}4.3197(3 \\
)\end{array}$ & $0.064(1)$ & 0.39 \\
\hline $\begin{array}{c}\mathrm{Ti}_{3} \mathrm{AlC}_{2} \text {-LD- } \\
\mathrm{HT}\end{array}$ & 3.73 & $\begin{array}{c}3.0699(2 \\
)\end{array}$ & $18.543(2)$ & $0.1313(4)$ & $0.599(1)$ & $44.4(8)$ & $\begin{array}{c}4.3082(3 \\
)\end{array}$ & $0.05(1)$ & 0.34 \\
\hline & & & & $\begin{array}{c}\mathrm{Ti}_{\perp \_} \mathrm{Z} \\
\text { position }\end{array}$ & & & & & \\
\hline
\end{tabular}




\begin{tabular}{|c|c|c|c|c|c|c|c|c|c|}
\hline $\begin{array}{l}\mathrm{Ti}_{2} \mathrm{AlC}- \\
\text { pristine }\end{array}$ & 3.2 & $\begin{array}{c}3.0616(2 \\
)\end{array}$ & $13.652(2)$ & $0.588(1)$ & ${ }^{a} \mathrm{n} / \mathrm{a}$ & $6.7(8)$ & $\begin{array}{c}4.3106(7 \\
)\end{array}$ & $0.0236(8)$ & 0.23 \\
\hline $\begin{array}{c}\mathrm{Ti}_{2} \mathrm{AlC}-\mathrm{LD}- \\
\mathrm{LT}\end{array}$ & 3.17 & $\begin{array}{c}3.0367(2 \\
)\end{array}$ & $13.882(1)$ & $0.5843(5)$ & ${ }^{a} \mathrm{n} / \mathrm{a}$ & $8.3(3)$ & $\begin{array}{c}4.3168(3 \\
)\end{array}$ & $0.157(1)$ & 0.66 \\
\hline $\begin{array}{c}\text { Ti }_{2} \text { AlC-LD- } \\
\text { HT }\end{array}$ & 2.44 & $\begin{array}{c}3.0585(3 \\
)\end{array}$ & $13.659(3)$ & $0.585(3)$ & ${ }^{a} \mathrm{n} / \mathrm{a}$ & $4.3(1)$ & $\begin{array}{c}4.3128(1 \\
)\end{array}$ & $0.0176(2)$ & 0.11 \\
\hline & & & & & & $\begin{array}{l}\text { TiN } \\
\text { wt.\% }\end{array}$ & $\begin{array}{l}\text { TiN a- } \\
\text { LP }\end{array}$ & & \\
\hline $\begin{array}{l}\mathrm{Ti}_{2} \mathrm{AlN}- \\
\text { pristine }\end{array}$ & 1.6 & $\begin{array}{c}2.9886(3 \\
)\end{array}$ & $13.640(2)$ & $0.587(2)$ & ${ }^{a} \mathrm{n} / \mathrm{a}$ & $3.23(2)$ & $\begin{array}{c}4.2329(2 \\
)\end{array}$ & $0.015(1)$ & 0.16 \\
\hline $\begin{array}{c}\mathrm{Ti}_{2} \mathrm{AlN}-\mathrm{LD}- \\
\text { LT }\end{array}$ & 2.2 & $\begin{array}{c}2.9808(6 \\
)\end{array}$ & $13.714(4)$ & $0.590(1)$ & ${ }^{a} \mathrm{n} / \mathrm{a}$ & $11.6(1)$ & $\begin{array}{c}4.2336(1 \\
)\end{array}$ & $0.0262(2)$ & 0.20 \\
\hline $\begin{array}{c}{ }^{\mathrm{b}} \mathrm{Ti}_{2} \mathrm{AlN}-\mathrm{LD}- \\
\mathrm{HT}\end{array}$ & 2.6 & $\begin{array}{c}3.0086(3 \\
)\end{array}$ & $13.664(4)$ & $0.570(2)$ & ${ }^{a} \mathrm{n} / \mathrm{a}$ & $13(1)$ & $\begin{array}{c}4.2223(3 \\
)\end{array}$ & $0.125(2)$ & 0.58 \\
\hline
\end{tabular}

Numbers in parentheses represent one standard deviation of the last significant digit.

a In $\mathrm{M}_{2} \mathrm{AX}$ compounds, the $\mathrm{C}$-atom $\mathrm{z}$ position is fixed at the origin.

b In the case of $\mathrm{Ti}_{2} \mathrm{AlN}$, at high temperature, $36(3) \mathrm{wt} . \% \mathrm{Ti}_{4} \mathrm{AlN}_{3}$ content was detected. With a-LP of

2.9931 and c-LP of 22.986, the lattice was distorted from pristine, at 2.988 and 23.372 , for a-LP and cLP, respectively.

Table 2

Room temperature resistivity and irradiation defect size of MAX phases after neutron $(>0.1 \mathrm{MeV})$ irradiation of up to $0.1 \mathrm{dpa}$ at $360(20)^{\circ} \mathrm{C}$ or $695(25)^{\circ} \mathrm{C}$ 


\begin{tabular}{|c|c|c|c|c|c|c|}
\hline \multirow[t]{2}{*}{ Composition } & \multicolumn{4}{|c|}{$\rho(\mu \Omega \mathrm{m})$} & \multicolumn{2}{|c|}{$\begin{array}{l}\text { Mean dislocation loop size (nm } \\
\text { [Areal density] (defects } \mathrm{m}^{-2} \text { ) }\end{array}$} \\
\hline & Pristine & Reference & $360(20)^{\circ} \mathrm{C}$ & $695(25)^{\circ} \mathrm{C}$ & $360(20)^{\circ} \mathrm{C}$ & $695(25)^{\circ} \mathrm{C}$ \\
\hline $\mathrm{Ti}_{2} \mathrm{AlC}$ & $0.31(4)$ & $\begin{array}{l}0.32[30] \\
0.23[32] \\
0.39[33]\end{array}$ & $0.75(1)$ & $0.44(1)$ & $\begin{array}{l}<15 \\
{[-]}\end{array}$ & $\begin{array}{c}51(21) \\
{\left[7.7 \times 10^{13}\right]}\end{array}$ \\
\hline $\mathrm{Ti}_{3} \mathrm{AlC}_{2}$ & $0.262(8)$ & $\begin{array}{l}0.353[30] \\
0.287[32]\end{array}$ & $2.84(2)$ & $0.39(1)$ & $\begin{array}{c}75(25) \\
{\left[1.2 \times 10^{14}\right]}\end{array}$ & $\begin{array}{c}{ }^{c} 27(7) \\
{ }^{c}\left[8.9 \times 10^{13}\right]\end{array}$ \\
\hline $\mathrm{Ti}_{2} \mathrm{AlN}$ & $0.37(1)$ & $\begin{array}{l}{ }^{\mathrm{a}} 0.25[30] \\
{ }^{\mathrm{b}} 0.343[30]\end{array}$ & $1.46(1)$ & $0.25(1)$ & - & - \\
\hline $\mathrm{Ti}_{3} \mathrm{SiC}_{2}-\mathrm{FG}$ & $0.21(1)$ & $\begin{array}{l}0.23[29] \\
0.23[31]\end{array}$ & $1.1(1)$ & $0.23(1)$ & - & - \\
\hline $\mathrm{Ti}_{3} \mathrm{SiC}_{2}-\mathrm{CG}$ & $0.21(1)$ & $\begin{array}{l}0.23[29] \\
0.23[31]\end{array}$ & $2.2(1)$ & $0.24(1)$ & - & - \\
\hline
\end{tabular}

a $\mathrm{Ti}_{2} \mathrm{AlN}$ prepared with elemental powder mixture.

b $\mathrm{Ti}_{2} \mathrm{AlN}$ prepared with commercially available pre-reacted powder from Kanthal, Sweden.

c Triangular defects form at high temperature in $\mathrm{Ti}_{3} \mathrm{AlC}_{2}$, edge length is listed. 

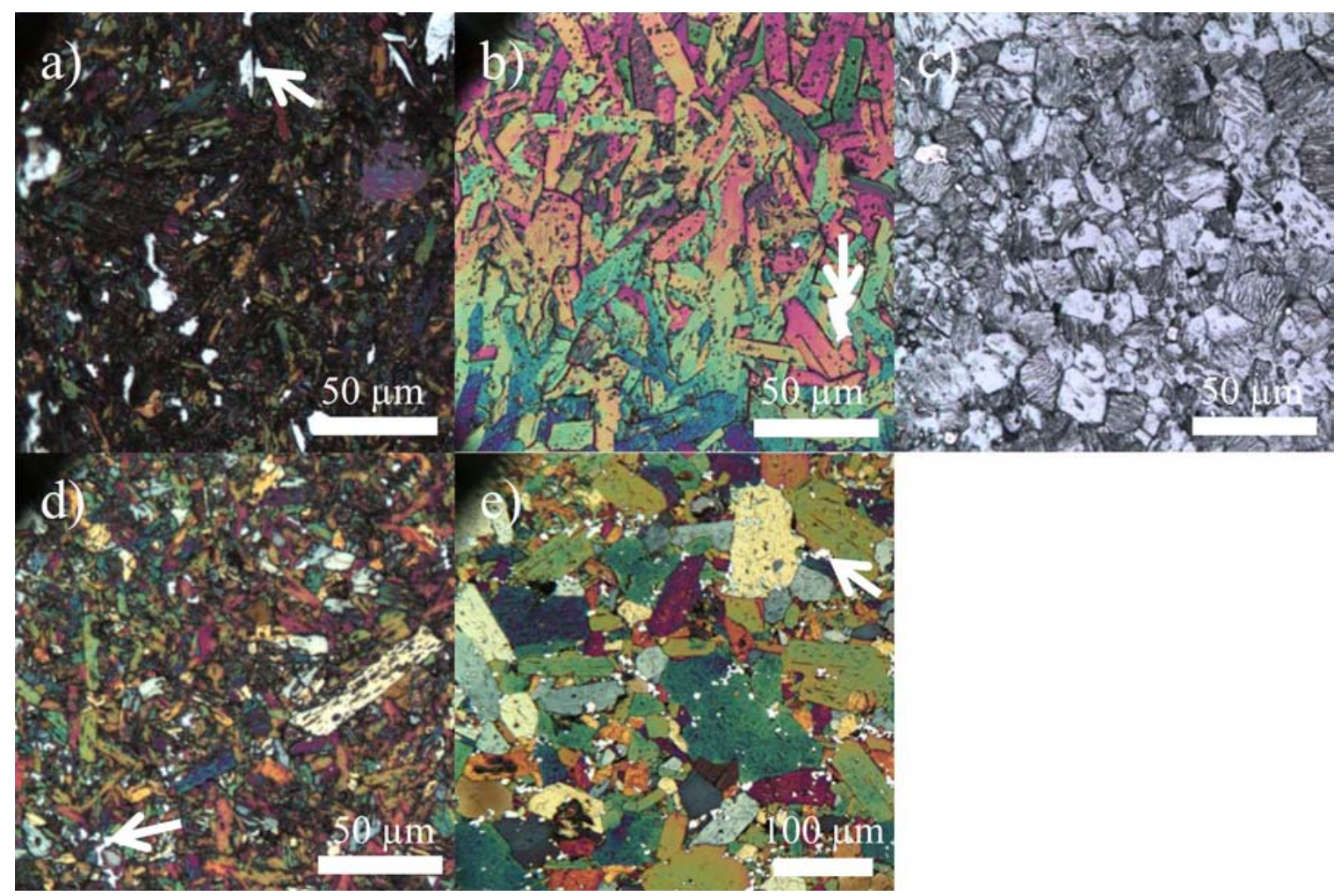

Figure 1. 


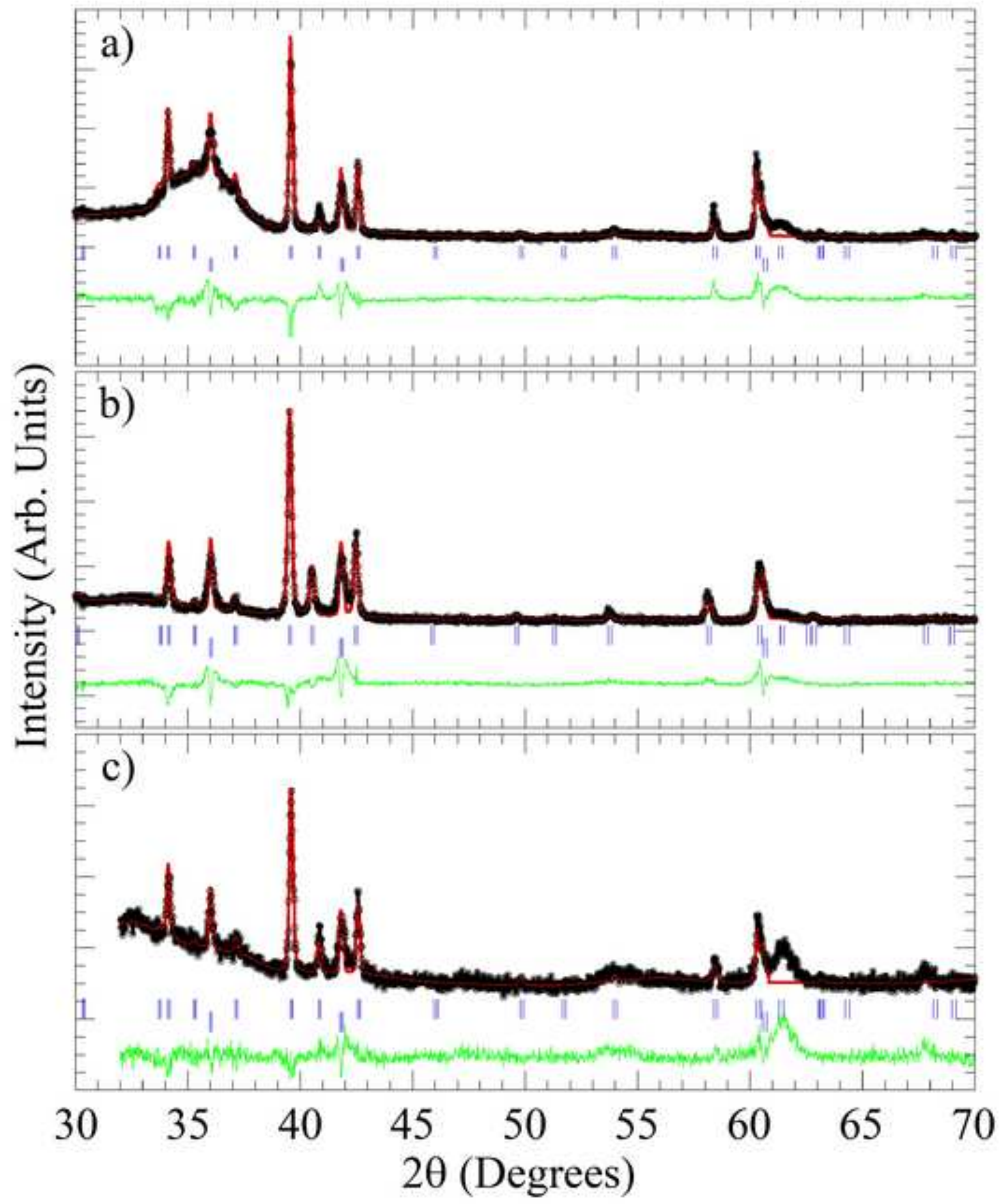

Figure $\mathrm{\square}$. 


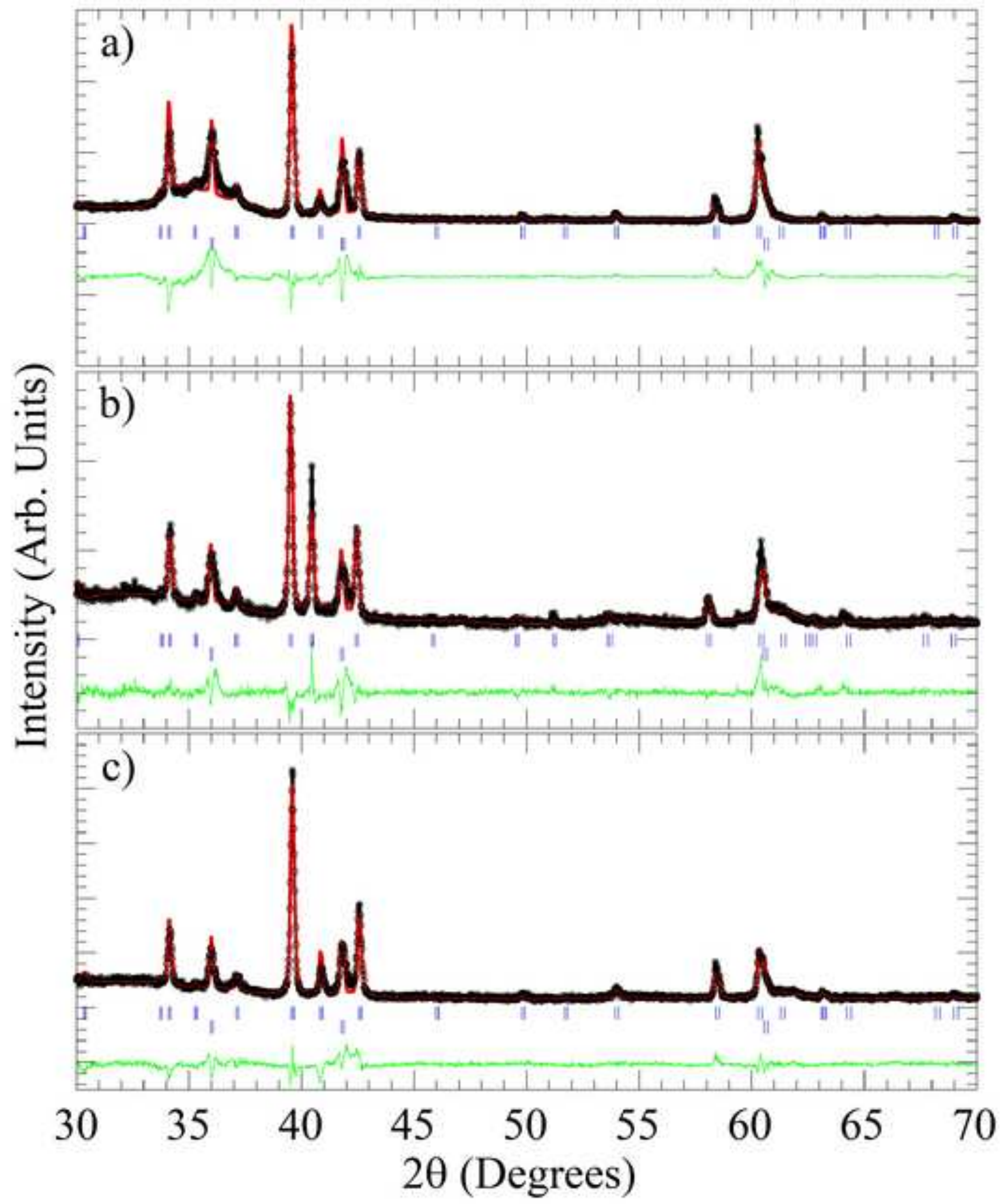

Figure $\mathrm{Q}$. 


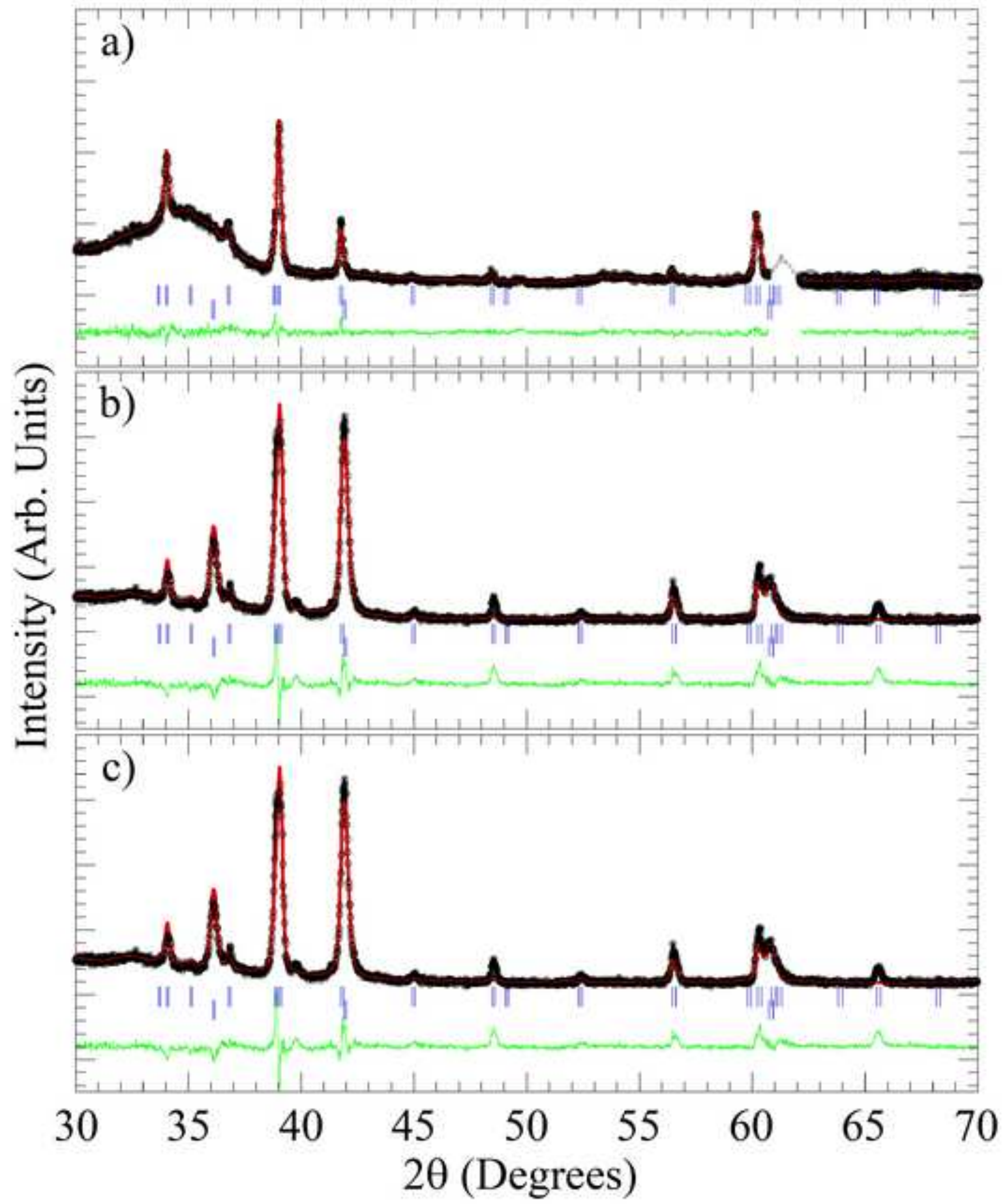

Figure $\mathrm{B}$. 


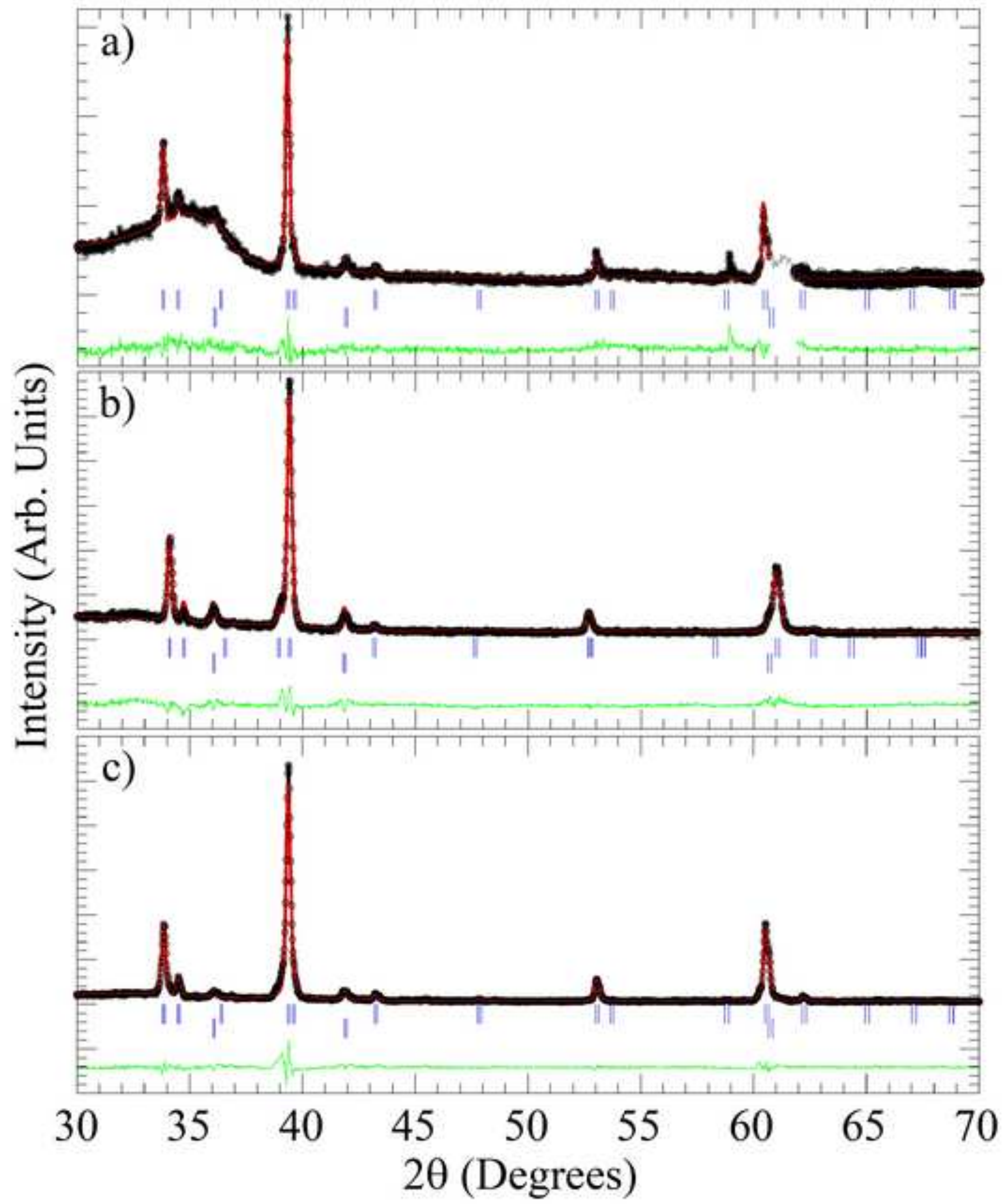

Figure $\mathrm{Q}$. 


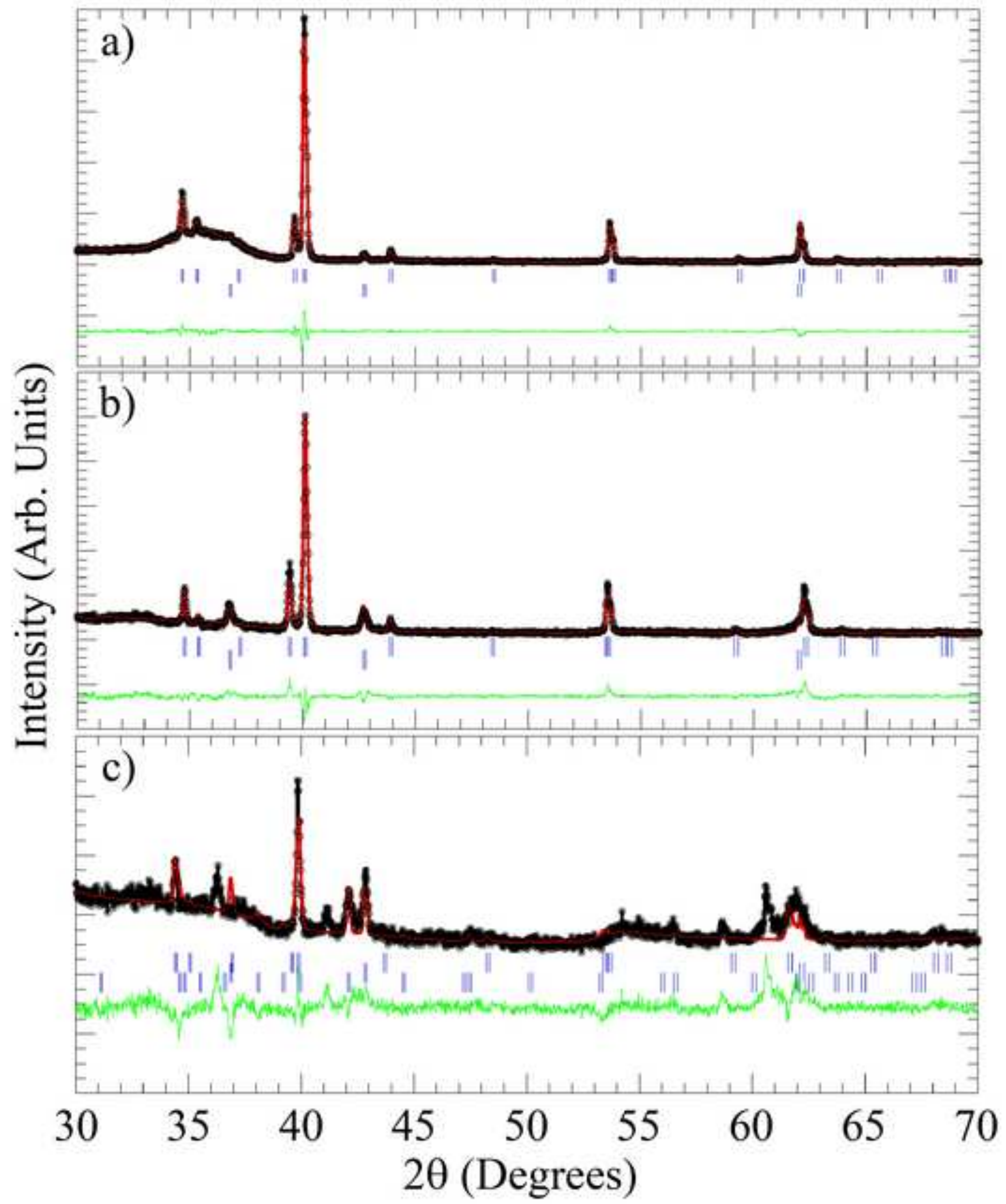

Figure 6. 

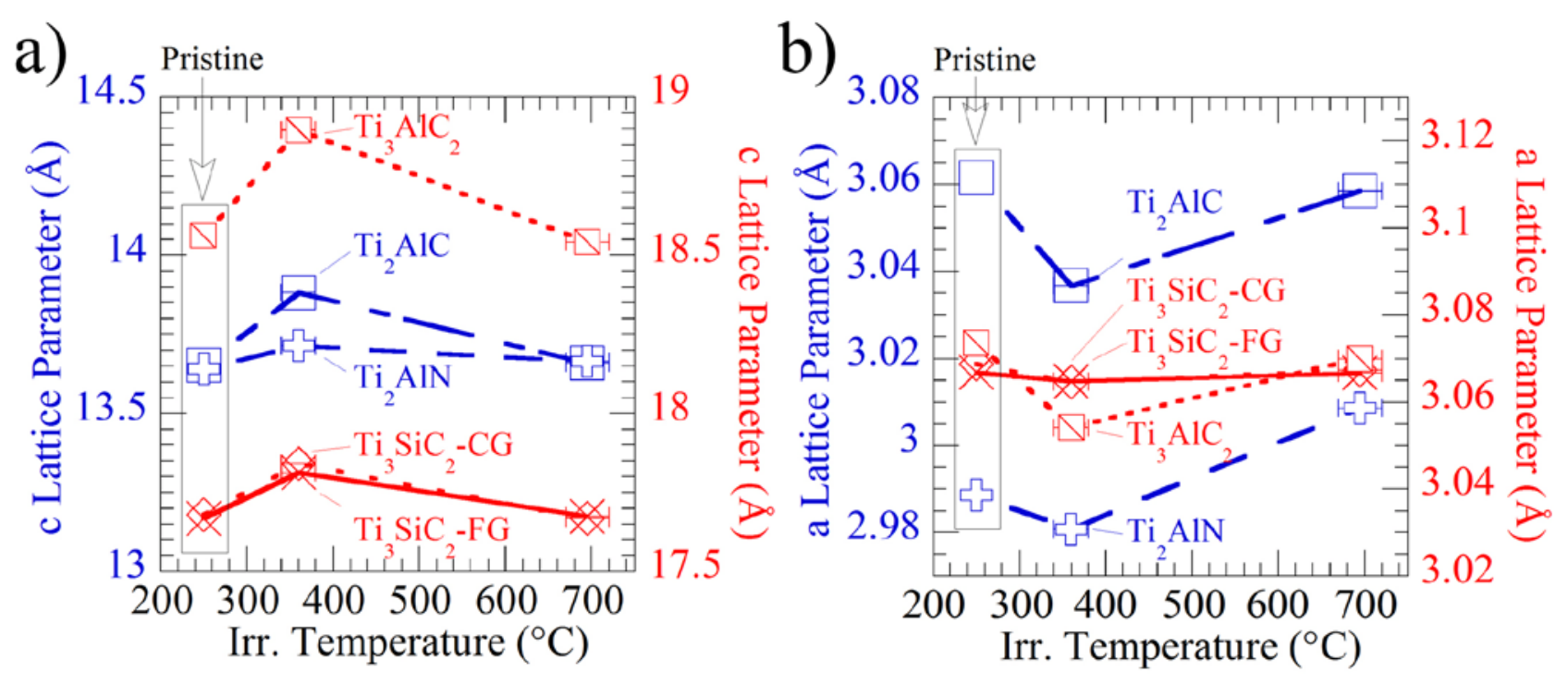

Figure 7. 


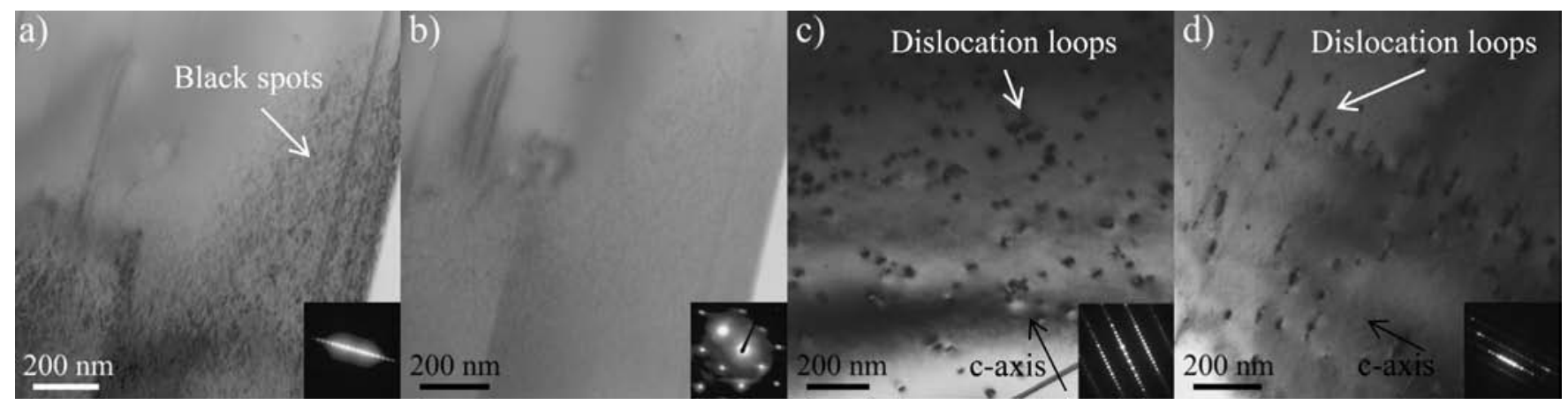

Figure 8. 


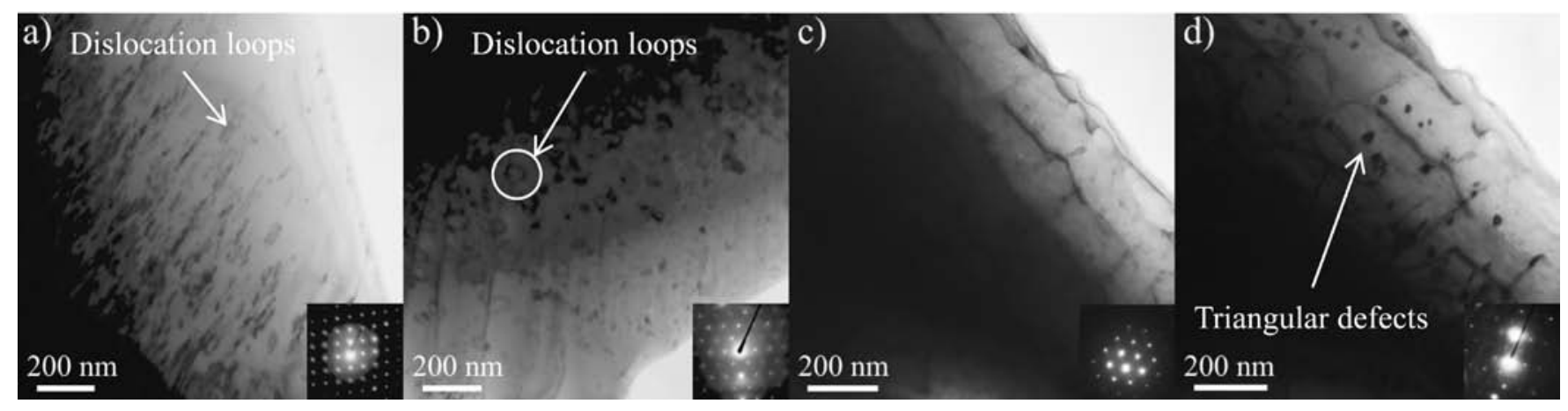

Figure 9. 